\title{
Simone Martini paints Robert of Anjou
}

\author{
Angevin Portraiture between Naples and Assisi
}

\author{
Nicolas Bock
}

The abundance of royal imagery in the Angevin lands - be it sculpted effigies or painted miniatures, panel paintings, or wall frescoes - has incited much research on the entwinement of the dynasty's representational strategies with the politics and religion of the time. Ferdinando Bologna's 1969 inquiry into the significance of Simone Martini's Saint Louis Altarpiece, which features a portrait of Robert of Anjou, is a landmark in this field (Figure. 7.1) ${ }^{1}$. Since then, many publications have further elucidated the importance of Angevin royal images, addressing issues of their chronology, patronage, meaning, and function. While the various iconographic facets of Angevin royal imagery have therefore received much attention, the visual and stylistic specifics of Angevin royal portraiture have been less studied, with the identification of depicted persons being mostly assured by heraldry.

Nearly every member of the Angevin dynasty appears in images, including the kings and queens and their sons and daughters accompanied by spouses

1 Ferdinando Bologna, "Povertà e umiltà: il San Ludovico di Simone Martini," Studi storici 10 (1969), 231-59; Ferdinando Bologna, I pittori alla corte Angioina di Napoli (1266-1414) (Rome, 1969), pp. 147-77; Julian Gardner, "Saint Louis of Toulouse, Robert of Anjou, and Simone Martini," Zeitschrift für Kunstgeschichte 39 (1976), 12-33 (with older bibliography); Lisa Monnas, "Dress and Textiles in the St. Louis Altarpiece: New light on Simone Martini's Working Practice," Apollo 137 (1993), 166-74; Lorenz Enderlein, "Zur Entstehung der Ludwigstafel des Simone Martini," Römisches Jahrbuch der Bibliotheca Hertziana 30 (1995), 135-49; Ferdinando Bologna, "La canonizzazione di San Ludovico di Tolosa e l'origine assisiate dell'ancona napoletana di Simone Martini," in Modelli di lettura iconografica. Il panorama meridionale, ed. Mario Alberto Pavone (Naples, 1999), pp. 17-48; Louise Caldi, The King and His Brother. Simone Martini's Louis of Toulouse Crowning Robert of Anjou and the Visual Language of Power, PhD thesis (Rutgers, State University of New York, 2002); Mario Gaglione, "Il San Ludovico di Simone Martini: manifesto della santità regale angioina," Rassegna storica salernitana 58 (2012), 9-125; Francesco Aceto, "Per Simone Martini pittore: ancora sull'iconografia del 'San Ludovico' del Museo di Capodimonte a Napoli," in Da Ludovico d'Angiò a san Ludovico di Tolosa. I testi e le immagini. Atti del Convegno internazionale di studio per il VII centenario della canonizzazione (1317-2017), Napoli - S. Maria Capua Vetere, 3-5 novembre 2016, eds. Teresa D'Urso, Alessandra Perriccioli Saggese, and Daniele Solvi (Spoleto, 2017), pp. 335o. For the original placement see below n. 27 .

(C) NICOLAS BOCK, 2022 | DOI:10.1163/9789004511583_009

This is an open access chapter distributed under the terms of the CC BY-NC 4.o licen\$l.colas Bock - 9789004511583 Downloaded from Brill.com04/26/2023 10:40:02AM 
and children. Indeed, the Angevins excelled in the use of personalized visual representations, and their images surpassed in quantity those of nearly all other ruling houses of the time - except, of course, the French royal family, the Church, and the papacy. One of the reasons for this abundance was their insistent use of funeral monuments, on which the deceased and other members of the family were represented. ${ }^{2}$ These sumptuous Angevin memorials occupied all the major Neapolitan churches. Beyond these, images of the royal family appeared also in monumental frescoes and in panel paintings and miniatures. Angevin imagery was thus omnipresent in Naples. When it was not figurative, it displayed their colourful coat of arms; covering the walls and ceilings of churches, chapels, and palaces, these signs reminded everyone of who was in charge of the kingdom. ${ }^{3}$

\section{Likeness in Death}

The personal presence that emanates from these images can still be experienced today, as when, upon entering the church of Santa Chiara, the spectator becomes aware of the nearly life-size sculptural figure of King Robert

2 The bibliography on this subject is large and steadily growing. See especially the monographs by: Lorenz Enderlein, Die Grablegen des Hauses Anjou in Unteritalien. Totenkult und Monumente 1266-1343 (Worms, 1999); Tanja Michalsky, Memoria und Repräsentation. Die Grabmäler des Königshauses Anjou in Italien (Göttingen, 2000); Nicolas Bock, Kunst am Hofe der Anjou-Durazzo. Der Bildhauer Antonio Baboccio (1351-um 1423) (Berlin, 2001). More recently: Mirko Vagnoni, "Una nota sulla regalità sacra di Roberto d'Angiò alla luce della ricerca iconografica," Archivio storico italiano 167 (2009), 253-67; Paola Vitolo, "Imprese artistiche e modelli di regalità al femminile nella Napoli della prima età angioina," Archivio storico per le province napoletane 126 (2009), 1-54, esp. 34-44; Vinni Lucherini, "Le tombe angioine nel presbiterio di Santa Chiara a Napoli e la politica funeraria di Roberto d'Angiò," in Medioevo. I committenti. Atti del convegno, Parma, 21-26 settembre 2010, ed. Arturo C. Quintavalle (Milan, 2011), pp. 477-504; Mirko Vagnoni, "Royal Images and Sacred Elements in Norman-Swabian and Angevin-Aragonese Kingdom of Sicily," Eikon/Imago 4 (2013), 10722; Paola Vitolo, "Ecce rex vester. Christiformitas e spazio liturgico," in La chiesa e il convento di Santa Chiara. Committenza artistica, vita religiosa e progettualità politica nella Napoli di Roberto d'Angiò e Sancia di Maiorca, eds. Francesco Aceto, Stefano D'Ovidio, and Elisabetta Scirocco (Battipaglia, 2014), pp. 227-74; Nicolas Bock, "La visione del potere. Cristo, il re e la corte angioina," in Cristo e il potere. Teologia, antropologia e politica, eds. Laura Andreani, and Agostino Paravicini Bagliani (Florence, 2017) pp. 211-24.

3 One need only recall the vault decoration of Santa Maria Donnaregina. On the relationship between the coat of arms and the figurative portrait, see: Hans Belting, "Wappen und Porträt. Zwei Bildmedien des Körpers," in Das Porträt vor der Erfindung des Porträts, eds. Martin Büchsel, and Peter Schmid (Mainz, 2003), pp. 89-100. 
enthroned in majesty above the altar, looking out over the nave as part of the king's monumental tomb (Figure. 7.2). ${ }^{4}$ Robert's seated figure is placed under a canopy and in front of a niche patterned with heraldry. An inscription directly beneath it underscores his presence, addressing the spectator and inviting him or her to recognize (cernere) the king: CERNITE ROBERTUM REGEM VIRTUTE REFERTUM. The statue would seem, therefore, to perfectly exemplify the essence of a royal portrait. Image, heraldry, and inscription all guarantee the identity of the person represented. While the artistic rendering imbues Robert with an individualized physiognomy, the inscription goes beyond this in calling upon the beholder to recognize - or better, to discern - the king not only physically but also through his moral qualities. The sculpture embodies the king's outer appearance as well as his inner character. ${ }^{5}$

Robert appears five times on the same monument, but the rendering of his face varies. ${ }^{6}$ While the face of his gisant accentuates the signs of age and death in a most expressive manner, thus personalizing his face to the utmost,

4 On Robert of Anjou, see esp.: Samantha Kelly, The new Solomon. Robert of Naples (13091343) and fourteenth-century kingship (Leiden, 2003). On the monument, see: Enderlein, Die Grablegen, pp. 167-88; Michalsky, Memoria, pp. 325-41 (with bibliography); Damian Dombrowski, "'Cernite' - Vision und Person am Grabmal Roberts des Weisen in S. Chiara," in Praemium Virtutis. Grabmonumente und Begräbniszeremoniell im Zeichen des Humanismus, eds. Joachim Poeschke, and Britta Kusch (Münster, 2002), pp. 35-6o (repr. in Der Tod und die Künste, eds. Friederike Felicitas Günther, and Wolfgang Riedel (Würzburg, 2016), pp. 4999); Lucherini, “Le tombe," pp. 477-504; Stefano D’Ovidio, "Cernite Robertum Regem Virtute Refertum: la 'fortuna' del monumento sepolcrale di Roberto d'Angiò in S. Chiara," in La chiesa, eds. Francesco Aceto et al. (Battipaglia, 2014), pp. 275-312; Vitolo, "Ecce rex vester"; Stefano D'Ovidio, "Osservazioni sulla struttura e l'iconografia della tomba di re Roberto d'Angiò in Santa Chiara a Napoli," Hortus artium medievalium 21 (2015), 92-112.

5 Peter von Moos, Unverwechselbarkeit: Persönliche Identität und Identifikation in der vormodernen Gesellschaft (Cologne, 2004). For the origins of the persona-conception, see: Bruno Reudenbach, "Individuum oder Bildnis? Zum Problem künstlerischer Ausdrucksformen von Individualität im Mittelalter," in Individuum und Individualität im Mittelalter, eds. Jan A. Aertsen, and Andreas Speer (Berlin, 1996), pp. 807-18; Brigitte-Myriam Bedos-Rezak, When ego was imago. Signs of Identity in the Middle Ages (Leiden, 2011); Martin Büchsel, "Le portrait au Moyen Âge," Perspective 2 (2012), 401-06.

6 The king appears four times on his monument within the church, while a second gisant is to be found in the choir of the Poor Clares. According to Aldo De Rinaldis, "La tomba primitiva di Roberto d'Angiò," Belvedere 5 (1924), pp. 92-96 the latter might have belonged to Robert's provisional tomb. This idea was abandoned in subsequent research, however. Doubts concerning its medieval origins subsist: Enderlein, Die Grablegen, pp. 177-78. On the contrary, Giulietta Chelazzi Dini, Pacio e Giovanni Bertini da Firenze e la bottega napoletana di Tino di Camaino (Florence, 1996), pp. 31-31, attributes it to the two Florentine sculptors. See also: Mario Gaglione, Nuovi studi sulla Basilica di Santa Chiara (Naples, 1996), p. 15; Michalsky, Memoria, p. 329; Lucherini, “Le tombe," p. 484; D’Ovidio, "Osservazioni," p. 106. 
the king's kneeling statue in the commendatio animae scene is devoid of any personalizing features. Robert's relief image on the front of the sarcophagus, placed in the lowest register of the funeral monument and therefore well in sight of the spectator, shows the characteristically deeply incised nasolabial folds and the long marionette lines, but otherwise his face appears idealized. The same is true, although to a lesser extent, of his second gisant, shown in a Franciscan habit, on the reverse of the monument, which can be seen from the choir. Here, too, the typical traits of his face - the elongated head with somewhat hollow cheeks; the small, straight, and tightly shut mouth; the heavy nasolabial folds and marionette lines; and the prominent chin with a pronounced mental crease - can be easily recognized, but the overall rendering is rather smooth and any smaller folds have been effaced. The variations among Robert's portraits may relate to the iconographic context for each image and, in addition, were subject to the capabilities of the different sculptors at work.

While the exceptional quantity of Robert's images on his funeral monument has caused some astonishment, the individualization of his portraits comes as no surprise and has in fact permitted scholars to identify the king and discuss his presence in other works of art. Recently, Diana Norman discussed Angevin portraiture and patronage in Assisi, Siena, and Florence, with attention to the larger Italian context for the dynasty's image politics and their international implications. ${ }^{7}$ Mirko Vagnoni instead concentrates on the relationship between portraiture and kingship, discussing a small selection of Robert's portraits in terms of their role in conveying the sanctity of the king's rule. ${ }^{8}$ Angevin portraiture should be seen, he argues, in continuity with Norman and Hohenstaufen habits and traditions. Broadening Vagnoni's historical perspective, Katharina Weiger interprets Robert's portraits vaguely as a manifold but coherent body of images that were created as political instruments to strategically assert moral and religious authority. ${ }^{9}$ Her approach is

7 Diana Norman, Siena and the Angevins (1300-1350). Art Diplomacy, and Dynastic Ambition (Turnhout, 2018).

8 Vagnoni, "Una nota sulla regalità sacra," pp. 253-67.

9 Katharina Weiger, "The portraits of Robert of Anjou: self-representation as political instrument?," Journal of Art Historiography 17 (2017), 1-16, esp. 15. Differences in the rendering of Robert's physiognomy have been explained by the desire to depict different aspects of his personality. For the idea of image policy, see: Alessandro Barbero, "La propaganda di Roberto d'Angiò re di Napoli (1309-1343)," in Le forme della propaganda politica nel Due e Trecento. Atti del convegno internazionale, Trieste, 2-5 marzo 1993, ed. Paolo Cammarosano (Rome, 1994), pp. 111-31; Michelle M. Duran, "The politics of art: imaging sovereignty in the Anjou Bible," in The Anjou Bible. A royal Manuscript revealed. Naples 1340, eds. Lieve Watteeuw, and Jan van der Stock (Paris, 2010), pp. 73-93. 
not without its complications, however, as it applies the modern concept of 'portraiture' to a wide range of artworks of varying character, size, date, and function. Stefania Paone had previously underlined the methodological problems inherent in interpreting all royal portraits as a coherent group mobilized as 'iconographic propaganda.' In particular, she stressed the issues of audience and reception: many of these images, especially the miniatures, would only have been seen within a very small circle, while others were destined for a larger audience..$^{10}$ It is thus problematic to approach in the same manner a miniature in the margin of a manuscript, for example, showing Robert playing chess, and a monumental statue in a publicly accessible church, showing the king in majesty.11

There are further issues that must be considered. While it is generally acknowledged that Simone's Saint Louis Altarpiece (1317-1319) is the earliest extant example of Robert's portrait (figures. 7.1, 7.3), its place within the longer chronology of Angevin portraiture has never been adequately addressed. ${ }^{12}$ Did Simone's portrait of Robert of Anjou provoke a change or an increase in royal portraits? And what were the respective roles of the artist and patron in this figurative individualization? Still to be addressed is the question of similitudo, or more specifically: did Robert always appear with the same naturalistic traits, or were there variations? And what might be the reason for these differences in his physical appearance? Did they depend on the artistic medium, the artist, or the function of the image?

\section{The King's Image: From Ideal to Individual}

To answer some of these questions, it is useful to move away from Robert's painted image in the Saint Louis Altarpiece and look to his portraits in other areas. The king's first sculpted image appears on the sarcophagus of the queen

10 Alessandro Tomei, and Stefania Paone, "Paintings and Miniatures in Naples. Cavallini, Giotto, and the Portraits of King Robert," in The Anjou Bible, eds. Watteeuw et al., pp. 5371, esp. 67. Alessandra Perricioli Saggese, "Il ritratto a Napoli nel Trecento : l'immagine di Roberto d'Angiò tra pittura e miniatura," in La fantasia e la storia. Studi di storia dell'arte sul ritratto dal Medioevo al Contemporaneo, ed. Giulio Brevetti (Palermo, 2019), pp. 37-45.

11 Samantha Kelly has pointed out the importance of the wide audience Robert found in his public preaching, in terms of the "dynamic and often experimental process of constructing royal policy and image." Kelly, The New Solomon, p. 15.

12 See, however: Harald Keller, "Die Entstehung des Bildnisses am Ende des Hochmittelalters," Römisches Jahrbuch für Kunstgeschichte 3 (1939), 227-354. 
mother Mary of Hungary (1257-1323) (Figure. 7.4) $\cdot{ }^{13}$ Her tomb, along with that of Catherine of Austria in San Lorenzo Maggiore, are the earliest extant monumental tombs of the Angevin dynasty in Naples, thus marking the beginning of a long and rich tradition. ${ }^{14}$ Mary's monument stands to the left of the nave in the convent church of Santa Maria Donnaregina, which she herself had founded. It already shows the canonical structure of all subsequent Angevin funeral monuments: at its base, caryatids symbolizing the virtues support the sarcophagus of the deceased. Above this, the camera funebris opens up, and two angels draw curtains to reveal the gisant of the queen. The roof of the tomb features the scene of the commendatio animae to the Virgin. A magnificent architectural canopy covers the entire structure. Mary's monument is also the earliest known tomb decorated with the iconographic scheme of the beata stirps, presenting the lined up members of the royal family as a saintly lineage ${ }^{15}$ The queen mother's descendants do not appear in the order of their birth but rather according to their dynastic importance: as the family's saint and therefore the most eminent, the second-born son, Louis of Anjou, occupies the center of the sarcophagus. To his right appears his older brother, Charles Martel, who had been crowned king of Hungary in 1292; to his left, assigned a placement indicating his lesser importance, sits the third-born son, Robert of Anjou, who was catapulted onto the throne of Naples when Louis renounced the worldly honours of kingship in order to follow Christ. Mary's other less important children follow on either side of this group of three.

A closer look at the two crowned brothers reveals their close resemblance. This resemblance is not genetic but stylistic, and not specifically Angevin but social: the identification of the figures relies on iconographic attributes crown, globe, sceptre - and on their positions within a hierarchy, rather than

13 On the monument, see:Enderlein, Die Grablegen, pp. 167-88; Michalsky, Memoria, pp. 32541 (with bibliography); Tanja Michalsky, "MATER SERENISSIMI PRINCIPIS. The tomb of Maria of Hungary," in The Church of Santa Maria Donna Regina. Art, Iconography and Patronage in Fourteenth-Century Naples, eds. Janis Eliott, and Cordelia Warr (Aldershot, 2004), pp. 45-6o.

14 On the monument of Catherine of Austria, see: Julian Gardner, "A Princess among prelates: a fourteenth century Neapolitan tomb and some northern relations," Römisches Jahrbuch für Kunstgeschichte 23/24 (1988), 29-6o; Francesco Aceto, "Tino di Camaino a Napoli: una proposta per il sepolcro di Caterina d'Austria e altri fatti angioini," Dialoghi di storia dell'arte 1 (1995), 10-27; Enderlein, Die Grablegen, pp. 76-89, 189; Michalsky, Memoria, pp. 281-89 (with further bibliography).

15 Tanja Michalsky, "Die Repräsentation einer Beata Stirps: Darstellung und Ausdruck an den Grabmonumenten der Anjous," in Die Repräsentation der Gruppen. Texte, Bilder, Objekte, eds. Otto Gerhard Oexle, and Andrea von Hülsen Esch (Göttingen, 1998), pp. 187224, esp. 191-95. 
on individual physiognomy. The family members' facial appearances are obviously stereotyped according to social standards, as evident in the foreveryouthful saint and the beautiful, clear-cut, and elongated faces of the kings, as well as in the secondary importance assigned to variations in age and seemingly distinctive features. For example, Charles Martel had died, at the age of 25,28 years before the creation of this tomb monument, whereas Robert was 46 years old at this point. The idealized appearance of these two brothers differs tellingly from the treatment of the non-ruling family members: individuality was clearly taken to be a flaw in the representation of kingship.

This kind of idealization can be traced back to Hohenstaufen images. Frederick II's seated statue on the gate of Capua, known to us through a drawing by Seroux d'Agincourt, featured comparably idealized facial forms. ${ }^{16}$ The royal effigies in Saint-Denis, which were sculpted during the campaign of 1264, are another prominent example. ${ }^{17}$ On the tomb, the same can be said of the gisant of Mary of Hungary herself. She does not appear to be 64 years of age, the mother of 14 children, but rather a virtuous and angelic princess, ready for paradise.

Some 20 years later, however, the situation in Naples had changed. In King Robert's gisant in Santa Chiara, which was completed after the king's death in 1343, the emphasis on distinguishing aspects of the king's physiognomy is not explicable only by the type of image - a gisant supposedly drawing upon the naturalistic tradition of the death mask, as is sometimes suggested. ${ }^{18}$ Rather, this individualizing approach characterizes all the images of King Robert from this period.

According to a photograph of Robert's funeral monument taken before the Allied bombing in 1944, the statue of the seated king had an angular face with a stern expression (Figure. 7.2) ${ }^{19}$ We find similar facial traits, as well as a comparable staging of the king on a throne under a baldachin, in a miniature in

16 Peter Cornelius Claussen, "Die Statue Friedrichs II. vom Brückentor in Capua (12341239): der Befund, die Quellen und eine Zeichnung aus dem Nachlaß von Seroux d'Agincourt," in Festschrift für Hartmut Biermann, eds. Christoph Andreas, Mareike Bückling, and Roland Dorn (Weinheim, 1990), pp. 19-39, 291-304; Peter Cornelius Claussen, "Stauferbilder - Bildnisse der Staufer," in Verwandlungen des Stauferreichs, eds. Bernd Schneidmüller, Stefan Weinfurter, and Alfred Wieczorek (Darmstadt, 2010), pp. 350-76; Valentino Pace, "Friderizianische Bildnisse," in Verwandlungen des Stauferreichs, eds. Schneidmüller et al., pp. $34-52$.

17 Georgia Sommers Wright, "A Royal Tomb Program in the Reign of St. Louis," Art Bulletin 56 (1974), 224-43.

18 Chelazzi Dini, Pacio e Giovanni Bertini, p. 21, fig. 5 .

19 Chelazzi Dini, Pacio e Giovanni Bertini, p. 19, fig. 4. 
the Anjou Bible, painted only a few years before the funeral monument's commission and intimately related to it. ${ }^{20}$ The same elements appear also in nonNeapolitan miniatures, for instance the famous double-page scene in the honorific poetry book by Convenevole of Prato, where the personification of Ytalia pleads her case before the king (Figure. 7.5). ${ }^{21}$ Here, the once-idealized king has become an older man, with dry skin stretched over his face and his profile distinguished by a long nose and tightly closed, thin lips. The coif or cale - a type of headscarf that Robert wore consistently, such that it became a personalized fashion attribute of his - complements the other recognizable facial features. ${ }^{22}$ For instance, on the basis of the cale and his elongated face and in spite of the absence of any royal insignia, Chiara Frugoni identifies Robert among the onlookers in Ambrogio Lorenzetti's fresco of Saint Louis kneeling

20 Leuven, Katholieke Universiteit, Faculty of Theology, Maurits Sabbe Library, cod. 1. See the extensive publication: The Anjou Bible, eds. Watteeuw et al.

21 Convenevole da Prato, Regia carmina, ed. and trans. Cesare Grassi (Cinisello Balsamo, 1982); Ernst Saenger, "Das Lobgedicht auf König Robert von Anjou. Ein Beitrag zur Kunstund Geistesgeschichte des Trecento," Jahrbuch der Kunsthistorischen Sammlungen in Wien 84 (1988), 7-91; Alessandro Tomei, "I Regia Carmina dedicati a Roberto d'Angiò nella British Library di Londra: un manoscritto tra Italia e Provenza," Arte medievale 6/4 (2016), 201-12; Caroline Smout, Sprechen in Bildern - Sprechen über Bilder: die allegorischen Ikonotexte in den Regia Carmina des Convenevole da Prato (Köln, 2017); Norman, Siena and the Angevins, pp. 30-32, n. 89 .

22 With the wearing of the crown being reserved for high feast days, popes, emperors, and kings normally wore a cale, a garment modeled after the pope's vestment, as a sign of consecrated clerical status conferred by the unction. Carra Ferguson O'Meary, Monarchy and Consent: The Coronation Book of Charles V of France: British Library MS Cotton Tiberius B. VIII (London, 2001), pp. 236-38. "Bishops and archbishops, anointed at their sacre, and anointed kings were required by the prevailing ecclesiastical and royal vestimentary codes to cover their heads at all times, to protect the anointed head from the touch of the profane and to signal their consecrated status." She refers to Jean Golein's Traité du sacre, fol. 49v: "Pour semblable cause apres linonction du chief larcevesque li met la coiffe sur le chief et la doit touz jours porter en signe quil a receu la sainte inonction ou chief et de plus digne saintete et afin quil en ait touz jours memoire il doit porter coiffe toute sa vie afin que le cresme nait aucune contagion moins honeste, car elle touche le corps penetrativement." Richard A. Jackson, "The Traité du sacre of Jean Golein," Proceedings of the American Philosophical Society 113 (1969), 305-24, esp. 317-18. For Robert, see, for instance, the illustrations in the Anjou Bible, on fol. 157v (Robert of Anjou in the role of the 'Wise Ecclesiastes') and fol. 309r (the presentation of the Anjou Bible). However, Charles I and Charles II are also depicted with cales (fol. 234r). For an attempt to identify Robert without the cale - and before his coronation - among the bystanders in the scene of the Death of Saint Martin in the chapel of Saint Martin in the lower church of Assisi, see: Diana Norman, "Sanctity, Kingship and succession: art and dynastic politics in the Lower Church at Assisi," Zeitschrift für Kunstgeschichte 73 (2010), 297-334, esp. 319-20. 
before the pope (1343-1344) in San Francesco, Siena. ${ }^{23}$ By that time, Robert's 'personalized' image had itself become standardized. ${ }^{24}$ Indeed, the same naturalistic traits can be found in all of the king's images from this later period, regardless of medium, artist, and function. Members of his family, however, did not benefit from the same individualization; their images remain visually anonymous, unless their identities are denoted by their arms or by inscriptions or other clues. ${ }^{25}$ The artistic approach to the king's portrait had evidently changed in the years after Simone Martini's Saint Louis Altarpiece. Chronology reveals itself to be a decisive factor when dealing with Angevin royal portraits.

The first painted image of Robert precedes the funeral monument to Mary of Hungary by at least six years. It is an enormous altarpiece depicting Saint Louis of Toulouse in majesty, which was painted by the Sienese artist Simone Martini ${ }^{26}$ and probably once stood in the church of San Lorenzo Maggiore

23 Chiara Frugoni, "Ambrogio Lorenzetti," in Pietro e Ambrogio Lorenzetti, ed. Chiara Frugoni (Florence, 2002), pp. 119-99, esp. 194; Norman, Siena and the Angevins, pp. 209-11, and figs. $84,100$.

24 Stephen Perkinson, "Portraits \& their Patrons: Reconsidering Agency in Late Medieval Art," in Patronage: Power \& Agency in Medieval Art, ed. Colum Hourihane (Princeton NJ, 2013), pp. 237-54, here 238, 243.

25 In the statues of the Ordre du Saint-Esprit du Droit-Désir ou Ordre du Noeud, King Louis of Taranto's face in profile has the same traits as that of the servant behind him. Paris, Bibliothèque nationale de France, ms. 4274, fol. 6v. Only in some miniatures, such as the frontispiece (fol. 2v), does the illuminator seem to have paid more attention to the twofold beard of the king. On the manuscript, see: Nicolas Bock, "L'Ordre du Saint-Esprit au Droit Désir. Enluminure, cérémonial et idéologie au 14 siècle," in Art, cérémonial et liturgie au Moyen Age, eds. Nicolas Bock, Peter Kurmann, Serena Romano, and JeanMichel Spieser (Rome, 2002), pp. 415-61; Andreas Bräm, Neapolitanische Bilderbibeln des Trecento (Wiesbaden, 2007), pp. 128-44; Alessandra Perriccioli Saggese, "Cristophoro Orimina: an illuminator at the Angevin court of Naples," in The Anjou Bible, eds. Watteeuw et al., pp. 113-25. In the Anjou Bible, the face of Andrew of Hungary, the first husband of Queen Joanna I, has no particular traits (fols. 249r, 278r), neither does Sancia (fol. 309r) nor Joanna (fols. 231v, 249r, 278r). The same applies to Joanna's face in her Book of Hours, Vienna, ÖNB, cod. 1921, fol. 234v.

26 Naples, Museo e Gallerie nazionali di Capodimonte. Main panel: 250 x $188 \mathrm{~cm}$, predella: 56 $\mathrm{X} 205 \mathrm{~cm}$. The signature in the predella reads: SYMON DE SENIS ME PINXIT. For the cleaning in 1959 by Leonello Tintori, see: IV Mostra di restauri: catalogo, ed. Soprintendenza delle Gallerie della Campania Laboratorio di Conservazione (Naples 196o), pp. $3^{2-38}$. 
(Figure. 7.1 $).{ }^{27}$ Dated shortly after 1317 on stylistic and iconographic grounds the canonization of Saint Louis of Toulouse took place on 7 April 1317 - the painting embodies the essence of Angevin political strategy concerning the succession in the Kingdom of Naples. When Charles Martel, the eldest son of Mary of Hungary and King Charles II, took the crown of Hungary in 129o, his father and Pope Boniface VIII bent heritage laws in order to pass the reign of Naples to the second-born son, Louis. He, however, followed his religious inclinations, trading the spreta pompa of the earthly regnum corruptibilis of Naples for the everlasting kingdom of heaven and thus renouncing his earthly rights of inheritance. What seemed most unlikely came to pass, with the succession falling to the third son, Robert: ${ }^{28}$

These are matters to be marveled at and unaccustomed to other people. For this man, placed in the highest sphere of virtues, renounced the right of the first-born and the kingship, held the ostentation of his royal throne in contempt, and traded for a corruptible kingdom an everlasting kingdom full of joy.

The far-reaching political significance of this altarpiece has been thoroughly examined, and its importance to Angevin portraiture has long been acknowledged. ${ }^{29}$ Louis is shown in a Franciscan habit and with episcopal regalia,

27 Several locations have been proposed: the Franciscan church of San Lorenzo Maggiore, where the painting is documented from the 16th century onwards; the Franciscan double monastery of Santa Croce (today Santa Chiara), of royal foundation but still under construction when the altarpiece was painted; and the probably semi-private oratory of Saint Louis, founded by the king's brother Philip of Taranto, adjacent to the cathedral. Adrian S. Hoch, "The Franciscan provenance of Simone Martini's Angevin St. Louis in Naples," Zeitschrift für Kunstgeschichte $5^{8}$ (1995), 22-38; Francesco Aceto, "Spazio ecclesiale e pale di 'primitivi' in San Lorenzo Maggiore a Napoli: dal 'San Ludovico' di Simone Martini al 'San Girolamo' di Colantonio," Prospettiva 137 (2010), 2-50; Diana Norman, "Politics and Piety: Locating Simone Martini's 'Saint Louis of Toulouse' altarpiece," Art History 33 (2010), 596-619. Norman, Siena and the Angevins, pp. 140-47 (with bibliography).

28 Canonization of Louis of Toulouse, 7 April 1317, bull of Pope John XXII: "Miranda est et aliis insueta! Vir namque hic virtutum positus in sublimi iure primogeniturae renuntiavit et Regno, Regalis solii spreta pompa, pro regno corruptibili aeternum ac plenum delitiis regnum mercans." Processus canonizationis et legendae variae Sancti Ludovici O.F.M. episcopi Tolosani, ed. Collegium Sanctae Bonaventurae (Quaracchi, 1951), pp. 395-9. For the context: Melanie Brunner, "Poverty and Charity: Pope John XxII and the Canonization of Louis d'Anjou," Franciscan Studies 69 (2011), 231-256.

29 For interpretations on the painting, see: Bologna, "La canonizzazione di san Ludovico," pp. 17-48; Klaus Krüger, "A deo solo et a te regnum teneo. Simone Martinis, Ludwig von Toulouse' in Neapel," in Medien der Macht. Kunst zu Zeiten der Anjous in Italien, ed. Tanja 
seated frontally on a lion-headed throne while receiving the crown of the eternal kingdom from angels above (aureola); his younger brother, Robert, kneels to his left, in full regal dress. ${ }^{30}$ As was customary in an enfeoffment ceremony, the latter holds his folded hands in front of him for the commendatio, ready to receive the earthly crown that his brother is preparing to place on his head (Figure. 7.3). Whereas the iconography of divine coronation follows Norman and older imperial prototypes, ${ }^{31}$ that of the king in profile can be linked to the antique tradition of imperial coins. ${ }^{32}$ Here, for the first time, Robert is ascribed all the individual physical traits we know from his later images. ${ }^{33}$

Michalsky (Berlin, 2001), pp. 79-119; Diana Norman, "The Sicilian connection. Imperial themes in Simone Martini's St. Louis of Toulouse altarpiece," Gesta 53 (2014), 25-45; Sarah Kozlowski, "Circulation, Convergence, and the Worlds of Trecento Panel Painting: Simone Martini in Naples," Zeitschrift für Kunstgeschichte 78 (2015), 205-38.

30 For the theological discussion on the nature of the crown above Louis's head and its definition as a sign of "accidental," individual beatitude as based on extraordinary merits, see: Edwin Hall, and Horst Uhr, "Aureola and Fructus. Distinctions of Beatitude in Scholastic Thought and the Meaning of Some Crowns in Early Flemish Painting," Art Bulletin 6o (1978), 249-70, here 256-58, and, "Aureola super Auream. Crowns and Related Symbols of Special Distinction in Late Gothic and Renaissance Iconography," Art Bulletin 67 (1985), 567-6o3. Palermo, Santa Maria dell'Ammiraglio, Robert II of Sicily crowned by Christ, $c$. 1143-1151. Vagnoni, "Una nota sulla regalità sacra," pp. 253-67.

32 Adrian S. Hoch, "The Antique Origins of an Emperor by Simone Martini," Paragone 38 (1987), 42-47. On the contrary: Marco Collareta, "Modi di presentarsi: taglio e visuale nella ritrattistica autonoma," in Visuelle Topoi. Erfindung und tradiertes Wissen in den Künsten der italienischen Renaissance, eds. Ulrich Pfisterer, and Max Seidel (München, 2003), pp. 131-49, esp. 132, 134. He goes back to Quintilian and Pliny the Elder to contrast the two types of portrait, tota facie against imago obliqua. Taking the portrait of Jean le Bon (13501364) in profile as an example, he links the frontal portrait to Christian icons expressing maiestas, whereas the profile should be seen as a 'consapevole dichiarazione di umiltà' in relationship to the confession of the faithful and the absolution of the priest. Interesting the use of the individualized profile in French royal iconography especially under Charles $\mathrm{v}$ in royal charters (Archives nationales, J/358/12, 1367) or on the parament of Narbonne in the Louvre. See: Claire Richter Sherman, The portraits of Charles V of France (13381380) (New York, 1969); Ghislain Brunel, Images du pouvoir royal. Les chartes décorées des Archives nationales, XIII ${ }^{e-X V}{ }^{e}$ siècle (Paris, 2005).

33 The young Robert in Simone's altarpiece possesses such a considerable likeness to the miniature of Convenevole da Prato's and Pacino da Buonaguida's Regia Carmina, London, British Library, Ms Royal 6 E IX, fol. 10v., that the two images perfectly illustrate the aging of the king: born in 1275, he was 37 years old at the time of the Saint Louis Altarpiece, and around 65 for the London miniature. For an image of Robert of Anjou in a French manuscript dating between 1321 and 1330, see: Brendan Cassidy, "An image of King Robert of Naples in a Franco-Italian manuscript in Dublin," Burlington Magazine 148 (2006), 31-33. Here, Robert has no resemblance with his Italian portraits, and neither does his brother Louis of Toulouse, who, unusually, appears with a beard. 
However, the question at hand is not about likeness or naturalism but about the chronology of Angevin portraiture and its implications. Why did Tino di Camaino not make use of the new and certainly impressive art of portraiture he had before his eyes in the Saint Louis Altarpiece, when he sculpted the funeral monument for Mary of Hungary six years later (Figure. 7.4)? Surely, Tino must have been aware of the artistic accomplishment of his fellow Tuscan, especially given that he had competed with him artistically in other works. ${ }^{34}$ How, then, could he have not adhered to what seems to us today to be a natural progression in art? Finally, and more importantly, what are the origins of Simone's naturalistic approach?

\section{$4 \quad$ Simone in Assisi}

The genesis of Simone Martini's Saint Louis Altarpiece is intimately linked to two of his major works: the Maestà in the Palazzo Pubblico in Siena and his frescoes in the lower church of San Francesco in Assisi, specifically, in the Elizabeth Chapel in the north part of the transept (figures. 7.6, 7.7) and in the chapel of Saint Martin, south of the nave. ${ }^{35}$ In Assisi, both commissions are politically linked to the Angevin dynasty, possibly even to the queen consort Mary of Hungary, who, among others, has been considered a possible patron for the Saint Louis Altarpiece. ${ }^{36}$ Although the timeline of the decoration of the lower church is rather complex, the appearance of the haloed Louis of Toulouse

34 For the close relation between Tino da Camaino and the painting of his time, especially Simone Martini, see: Max Seidel, "Das gemeißelte Bild im Trecento. Ein neuentdecktes Meisterwerk von Tino di Camaino," Pantheon 47 (1988), 4-13 (repr. as: "The sculpted image. Tino da Camaino measures up to Simone Martini," in Italian Art of the Middle Ages and the Renaissance, 2 vols, Architecture and Sculpture 2, ed. Max Seidel (Venice, 2005), pp. 627-38). The standing figure of Enrico Scrovegni by Marco Romano in the Arena Chapel (c. 1318-20) shows that naturalism was a possibility for sculpted portraits. Clario Di Fabio, "Memoria e modernità: della propria figura di Enrico Scrovegni e di altre sculture nella cappella dell'Arena di Padova, con aggiunte al catalogo di Marco Romano," in Medioevo: immagine e memoria, ed. Arturo C. Quintavalle (Milano, 2009), pp. 532-46.

For the chapel and its programme, see: Stella Mary Newton, "Tomaso da Modena, Simone Martini, Hungarians and St. Martin in fourteenth-century Italy," Journal of the Warburg and Courtauld Institutes 43 (1980), 234-38; Adrian S. Hoch, "St. Martin of Tours: his transformation into a chivalric hero and Franciscan ideal," Zeitschrift für Kunstgeschichte 50 (1987), 471-82; Brendan Cassidy, "Simone Martini's 'St Martin and the Emperor' and contemporary Italian politics," Zeitschrift für Kunstgeschichte 70 (2007), 145-58; Norman, "Sanctity, Kingship and succession," pp. 297-334.

36 Norman, "Sanctity, Kingship and succession," pp. 297-334. 
in the Elizabeth Chapel indicates a date of execution after his canonization in 1317. Yet, a dating of the frescoes to after 1319 would be unlikely, as Assisi was in the hands of the Ghibelline faction between 1319 and 1322, during which any attempts to glorify the Angevin cause would have been deemed hostile. ${ }^{37}$

Simone's paintings in the Elizabeth Chapel offer an important comparison to the portrait of Robert of Anjou in the Saint Louis Altarpiece. The Elizabeth Chapel is situated in the North-eastern corner of the transept; there, the scale of the fresco was limited both by a small passage in the east wall (leading to the Magdalen Chapel) and by a large opening in the north wall (leading to the chapel of Saint Nicholas). ${ }^{38}$ Simone's frescoes cover only the lower section of the two walls, the space above being decorated with Passion scenes by Pietro Lorenzetti. ${ }^{39}$

To contend with the peculiar placement of the chapel - i.e. to convincingly insert his paintings into the corner of the transept - Simone devised an illusionistic architectural structure for both walls. Above a polychrome-marble balustrade, he painted a white-marble loggia, within which half-length figures of various saints appear. At either end of the fresco and at the meeting point of the two walls, white-marble pilasters illusionistically support the marble cornice of the loggia, as does a series of four extremely thin gold columns on the north wall. Some of the saints rests their hands or set objects on the balustrade, reinforcing the illusion of an open space. Simone differentiated between the two walls. On the eastern wall, the Virgin and Child, flanked by Saint Ladislaus

37 Bologna, I pittori, pp. 151-52; Norman, Siena and the Angevins, pp. 167, 185, n. 35 .

38 The church of San Francesco in Assisi is oriented towards the west.

39 For the dating of Pietro Lorenzetti's frescoes to before 1320, see: Carlo Volpe, "Proposte per il problema di Pietro Lorenzetti," Paragone 23 (1951), 13-26; Hayden Maginnis, "The Passion Cycle in the Lower Church of San Francesco in Assisi: The Technical Evidence," Zeitschrift für Kunstgeschichte 39 (1976), 193-208; Maria Monica Donato, "Transetto settentrionale. Simone Martini," in La Basilica de San Francesco d'Assisi. Basilica inferiore / The Basilica of St Francis in Assisi. Lower Basilica, ed. Giorgio Bonsanti (Modena, 2002), n. 150-6o, pp. 424-26, 554-56o; Serena Romano, "Per la data della 'Crocifissione' nel transetto nord della chiesa inferiore di Assisi," Zeitschrift für Kunstgeschichte 78 (2015), 345-55. For the relation between Simone in the lower church of Assisi and his Siena Maestà, see: Irene Hueck, "Frühe Arbeiten des Simone Martini," Münchner Jahrbuch der bildenden Kunst 19 (1968), 29-6o; Ferdinando Bologna, I pittori, pp. 150-55; Joseph Polzer, "Simone Martini's two frescoes in the lower right transept of the church of San Francesco in Assisi," Arte cristiana, n.s. 72 (1984), 353-68; Luciano Bellosi, "Il 'pittore oltremontano' di Assisi, il Gotico a Siena e la formazione di Simone Martini," Prospettiva 121/124 (2006), 227-36 (originally published in: Simone Martini, Atti del convegno, Siena 1985, ed. Luciano Bellosi (Florence, 1988), pp. 39-47). On the dating, see: Luciano Bellosi, "Moda e cronologia. A) La decorazione della basilica inferiore di Assisi," Prospettiva 121/124 (2006), 428437 (originally published in: Prospettiva 10 (1977), 21-31). 
and Saint Elizabeth of Hungary, appear against an elaborately structured gold ground that imitates a precious piece of cloth (Figure. 7.6). ${ }^{40}$ Due to the white-marble framing, the resemblance to a 'living altarpiece' is striking. In turn, on the southern wall, Saints Francis, Louis of Toulouse, Elizabeth, Agnes of Bohemia, and Henry of Hungary stand against a blue ground, separated by thin gold columns (Figure. 7.7). The foreshortening of the architectural devices creates a strong illusionistic effect. The five saints vividly dialogue with one another, looking across the space and around the corner at the Virgin and Child group.

More than ever before, here Simone insisted on the liveliness and reality of the scene. He accentuated the interactions among the saints through their gestures and glances (Figure. 7.7). Moreover - and this is important for the question of portraiture - he gave each figure, and especially the male saints, a highly individualized appearance. For instance, Saint Francis is depicted with a sparse beard, and Saint Louis of Toulouse with an elongated, mule-like face. The same tendency can be observed on the adjacent wall, where Saint Ladislaus appears with facial stubble (Figure. 7.6); the impression of corporal neglect that this conveys is, however, overridden by the intense gaze from his blue eyes. Most remarkably, Simone insists on the somewhat sheepish look of Saint Louis of Anjou, which overtly contrasts with the handsomeness of the other two young saints in the fresco. This is especially noteworthy alongside the Neapolitan altarpiece that Simone was at work on in exactly these years, in which he gave the same Louis a much fresher, more child-like appearance (Figure. 7.1 ). Here, with rosy, roundish cheeks and wide-open eyes, Saint Louis bears no physiognomic similarity to his kneeling brother, Robert. In Assisi, however, Simone insisted on the physical resemblance between Louis and his brother in the Neapolitan altarpiece, thus producing a recognizable Angevin family appearance: elongated faces stretched with dry skin; sharply cut, horizontal eyebrows; and almond-shaped eyes. ${ }^{41}$

40 For the identification of the saints, see: Adrian S. Hoch, "The Dedication of the St Elizabeth Altar at Assisi," Burlington Magazine 133/1054 (1991), 36-37; Adrian S. Hoch, "Beata Stirps, royal patronage and the identification of the Sainted Rulers in the St. Elizabeth Chapel at Assisi," Art History 15 (1992), 279-95; Norman, Siena and the Angevins, p. 164.

41 Simone maintained this way of rendering Saint Louis, maybe slightly softened, for his image in the chapel of Saint Martin. In regard to the question of family likeness, the long nose of Charles I is already attested by Dante, Purgatorio VII, 124-127: "Anche al nasuto (Charles I) vanno mie parole / non men ch'a l'altro, Pier, che con lui canta, / onde Puglia e Proenza già si dole"; as well as by Giovanni Villani, Nuova Cronica, ed. Giuseppe Porta, 3 vols (Parma, 1990-91), I, VIII, 1, pp. 329-30: "Questo Carlo fu (...) grande di persona e nerboruto, di colore ulivigno, e con grande naso, e parea bene maestà reale più ch'altro signore." 
Simone's revolutionary modernity in these frescoes is attested by his work on the Maestà in Siena's Palazzo Pubblico. Starting with the upper border, Simone likely finished the Siena fresco in two campaigns between 1312 and $1315 .{ }^{42}$ It seems he then left to work in Assisi, when he returned to Siena to carry out some important restorations to his Maestà in $1321 .{ }^{43}$ Technical enquiries have shown that he replaced almost the entire lower part of the fresco, at the level of the four kneeling saints in the foreground. Although this restoration took place only six years after the fresco's first completion, the stylistic change is overwhelming. The new saints in the roundels of the lower frame convey a vivid humanity. Shown either presenting books or in the act of reading, they are rendered as individuals, as learned librarians or lively instructors. Their heads are shown in profile or slightly inclined in an inconspicuous movement of deliberation. As can be seen in the roundel of Saint Gregory (Figure. 7.8), Simone proved very attentive to the effects of light and to personal details, such as the faint stubble turning white with age or, on a head shown in profile, an irregular nose. Between the two campaigns, Simone's difference in approach to the saints is striking: the semblance to the maniera greca of the first campaign contrasts sharply to the human presence and liveliness of the saints painted during the second campaign, visible at the bottom of the fresco. This new, portrait-like quality can be attributed to Simone's experience working on the Saint Louis Altarpiece and on the Assisi frescoes.

Simone's Assisi experience seems to have been crucial to his development of a new, naturalistic approach to painting, which he then used for the portrayal of Robert of Anjou in the Saint Louis Altarpiece. A strong impetus for Simone's reflection on the use of naturalism in portraiture may have come from his encounter with the works of Giotto. Some contemporaries, such as Pietro d'Abano, had already praised Giotto for his ability to imbue his painted figures with such a life-likeness that anyone could recognize them on the streets. ${ }^{44}$

42 For the different stages of the execution of the Maestà, see: Alessandro Bagnoli, "I tempi della ,Maesta.' Il restauro e le nuove evidenze," in Simone Martini, ed. Luciano Bellosi (Florence, 1988), pp. 109-18, esp. 113-14; Alessandro Bagnoli, La Maestà di Simone Martini (Cinisello Balsamo, 1999), pp. 66-72; Pierluigi Leone de Castris, Simone Martini (Milano, 2003); Norman, Siena and the Angevins, pp. 53-56.

43 Bagnoli, La maestà, p. 85 .

44 Pietro d'Abano, Expositio in problematibus Aristotelis (1310), lib. 36, 1, § 3: "Solvit dupliciter dicens primo causam esse quia per imagines faciei representatur qualis fuerit dispositio 
For Pietro, this naturalistic ability was the result of Giotto's capacities of visual rhetoric, summarized under the concept of dispositio. Vasari likewise credited Giotto with being the inventor of portraiture: "introdusse il ritrar di naturale le persone vive, che molte centinaia d'anni non s'era usato." 45 Modern research has adopted this point of view, with scholars attempting to identify portraits in a number of his works. ${ }^{46}$ Peter Seiler has analysed in depth Vasari's view of Giotto and the question of portraiture. He shows how, between the first and second editions of his text, Vasari adapted what was a short, apodictic statement into a more subtle discourse highlighting Giotto's capacity as an imitator of nature more than as an inventor of portraiture. ${ }^{47}$ Moreover, Seiler shows

ipsius cuius est imago, et maxime cum fuerit depicta pictore sciente per omnia assimilare, puta Zoto, ut ea deveniamus in cognitionem illius ita, ut occurrens is cognoscatur ipsa vel sculpta, ut oboli denotans pretacti, vel statua per Ceusim facta Crotoniate, de qua Tullius Rhetorice veteris 2o." Peter Seiler, "Giotto als Erfinder des Porträts," in Das Porträt, eds. Büchsel et al., pp. 153-72, esp. 16o. On Pietro d'Abano as a physiognomic counsellor to Giotto, see: Hubert Steinke, "Giotto und die Physiognomik," Zeitschrift für Kunstgeschichte 59 (1996), 523-47. Stefania Paone, "Giotto ritrattista ? Qualche considerazione," in La fantasia e la storia. Studi di storia dell'arte sul ritratto dal Medioevo al Contemporaneo, ed. Giulio Brevetti (Palermo, 2019), pp. 47-61. Serena Romano, La O di Giotto (Milan, 2008), pp. ${ }^{130}-36$.

45 "Introducing the drawing from nature of living persons, which had not been practised for two hundred years." Giorgio Vasari, Le vite de' piu eccellenti pittori, scultori e architettori, nelle redazioni del 1550 e 1568 2, eds. Rosanna Bettarini, and Paola Barocchi (Florence 1967-), p. 97. Translation at https://arthistoryproject.com/artists/giorgio-vasari/the-livesof-the-artists/giotto/.

46 Jacob Burckhardt, "Das Porträt in der Malerei," in Jacob Burckhardt Werke. Das Altarbild. Das Porträt in der Malerei. Die Sammler. Beiträge zur Kunstgeschichte von Italien 6, eds. Stella van Boch, Johannes Hartau, Kerstin HengevossDürkop, and Martin Warnke (Munich, Basel, 2000), pp. 140-281, esp. 149. See in detail: Kurt Bauch, "Giotto und die Porträtkunst," in Giotto e il suo tempo. Atti del Congresso internazionale per la celebrazione del VII centenario della nascita di Giotto, 24 settembre-1 ottobre 1967, (Assisi, 1971), pp. 299-309; Wolfram Prinz, "Ritratto istoriato oder das Bildnis in der Bilderzählung. Ein frühes Beispiel von Giotto in der Bardikapelle," Mitteilungen des Kunsthistorischen Institutes in Florenz 30 (1986), 577-80; Johannes Thomann, "Pietro d'Abano on Giotto," Journal of the Warburg and Courtauld Institutes 54 (1991), 238-44; Steinke, "Giotto und die Physiognomik," pp. 523-47; Seiler, "Giotto als Erfinder," pp. 153-72. Sceptical however: Harald Keller, "Die Entstehung des Bildnisses," p. 298; Enrico Castelnuovo, " 'Propter quid imagines faciei faciunt.' Aspetti del ritratto pittorico nel Trecento," in Le metamorfosi del ritratto, ed. Renzo Zorzi (Florence, 2002), pp. 33-50; Enrico Castelnuovo, "Les portraits individuels de Giotto," in Le portrait individual. Réflexions autour d'une forme de representation XIIIe-XVe siècles, ed. Dominic Olariu (Bern, 2009), pp. 103-20.

47 It is no coincidence that this episode follows Cimabue's discovery of Giotto when he "ritraeva una pecora di naturale." Vasari, Le vite, p. 97. In the 1568 edition: "ma ancora divenne così buono imitatore della natura, che sbandì affatto quella goffa maniera greca, e riuscitò la moderna e buona arte della pittura, introducendo il ritrarre bene di naturale 
how Giotto constructed not portraits but 'facial composites' (Phantombilder) by using a repertoire of non-specific yet highly naturalistic traits. The artist employed this apparent naturalism especially for accompanying figures, who in this way acquired an imagined likeness that served as a rhetorical device, increasing the plausibility of the visual fiction. It was this procedure that opened up the way towards portraiture in art. ${ }^{48}$

Simone, in turn, elevated personalization to a higher level and assigned it a new artistic and intellectual quality. When he came to Assisi and encountered Giotto's art, he immediately seized upon the possibilities that the innovative approach of his Florentine counterpart had opened up in the field of visual fiction. Unlike Giotto, however, who used this method predominantly for his, iconographically speaking, secondary figures, including patrons, Simone conferred the new naturalism to the main figures of his pictures, namely, to the saints themselves, and made it a prominent visual tool. ${ }^{49}$ Saints and kings took on a new, life-like appearance and, consequently, a much more convincing presence.

It is certainly no coincidence that this change in Simone's attitude began in Assisi, with its ties to the Franciscan Order, which had deeply reflected on the use of images. Even more importantly, the order had developed specific strategies concerning the modes of representation of their eponymous saint. ${ }^{50}$ These included details like the presence and form of Francis's beard. ${ }^{51}$ In

le persone vive, il che più di dugento anni non s'era usato; e se pure si era provato qualcuno, come si è detto di sopra, non gli era cio riuscito molto felicemente, ne così bene a un pezzo, come a Giotto." Seiler, "Giotto als Erfinder," pp. 155-57 (for the contextualization of this change and further bibliography on Renaissance portraiture).

48 "Einstweilen scheint mir jedoch die Annahme attraktiv, daß Giotto mit seinen physiognomischen Innovationen neue künstlerische Möglichkeiten und Freiräume spielerisch auslotete und Erfindungen machte, die dazu führten, daß - es sei noch einmal Burckhardt zitiert - durch sein Vorbild, die ganze italienische Malerei dem Bildnis irgendwie die Pforte öffnete." Seiler, "Giotto als Erfinder," p. 172.

49 Seiler, "Giotto als Erfinder," pp. 165-69. Giuliano Pisani, I volti segreti di Giotto (Milan, 2008), pp. 194-21l. Stefania Paone, "Giotto e il 'ritratto' dei committenti," in Giotto pictor egregius, ed. Alessandro Tomei (Turin, 2017), pp. 319-353.

$5^{\circ} \quad$ On this, see: Chiara Frugoni, Francesco e l'invenzione delle stimmate (Turin, 1993).

51 Luciano Bellosi, "La barba di San Francesco (nuove proposte per il 'problema di Assisi')," Prospettiva 121/124 (2006), 143-65, esp. 143-46 (originally published in: Prospettiva 22 (1980), 11-34) shows, on the basis of the anonymous Vita di Cola di Rienzo of $c .1340$, the historic interpretations of fashion. Beards were considered to belong to people 'di pessima rascione,' whereas clean-shaven faces were associated with those 'per bene.' Bellosi then links the sudden appearance of images of the beardless Saint Francis (contrary to the information given by historical chronicles and to the earlier pictorial tradition) at the beginning of the 14th century with the political struggle within the Franciscan Order between the spirituali and the conventuali. He interprets Simone Martini's Saint Francis 
coming to Assisi, Simone therefore entered an intellectual ambiance that was very much aware of the possibilities of visual persuasion - including through portraiture - and this certainly contributed to his own attitude towards the use of mimetic devices in his art.

But it was not only the intellectual stimulus of the Franciscans that introduced Simone to the tenets of naturalism. Only a few metres away from his frescoes in the northern transept of the lower church of San Francesco was Giotto's still glaringly new, large fresco of the Crucifixion, completed in 1313 in the opposite (southern) transept. Lamenting the dead Christ, three Franciscan friars kneel at the foot of the Cross, in the foreground of the scene (Figure. 7.9). Flanked by Saint Francis and Saint Anthony, the friar in the middle lacks a halo, and his facial features - shown in profile - are so individualized as to suggest a (political) portrait. This figure has been identified with different prominent members of the order, most recently with Gonsalvo di Valboa, who in the basilica of Assisi in 1304 was elected minister general of the Franciscans. ${ }^{52}$ This fresco, executed by the most important artist of the time, confronted Simone directly with the most recent and magnificent example of Giotto's art of portraiture. Amid the specific intellectual surroundings of the Franciscans in Assisi, it was this unique combination of artistic inspiration and mimetic skill that led Simone to reflect on the possibilities of individualization and to push the limits of portraiture still further.

The difference between the family likeness used by Simone for Saint Louis in Assisi and his depersonalized, angelic image of the same person in his Neapolitan altarpiece demonstrates that the application of individualizing features followed the logic of rhetoric. It was not part of a common artistic language to be applied to anyone at any time. Moreover, what may seem to

in the lower church as manifesting the spiritual current supported by the Angevins. See: "Historiae Romanae fragmenta ab anno MCCCXXVII usque ad MCCCLIX," in Antiquitates italicae medii aevi, ed. Lodovico Antonio Muratori (Milan, 1738-42), vol. III, col. 307-09.

52 Others proposed Michele da Cesena, who became general of the order in 1316, and Francesco Damiani da Montefalco, brother of Saint Claire and minister of the province of Umbria. Romano, "Per la data." The name of Gonsalvo di Vilboa was first introduced by: Carl Strehlke, "Francis of Assisi. His Culture, His Cult and His Basilica," The Treasury of Saint Francis of Assisi. Exhibition catalogue New York, Metropolitan Museum, eds. Giovanni Morello, and Laurence B. Kanter (Milan, 1999), pp. 23-51. 
us an individualized portrayal may very well be just a combination of stereotypes. This was particularly true for royal images, which in turn could be used to forge new types of portraiture. Exemplifying the transfer of personalization from one 'portrait' to another, the sculpted head of a king (Figure. 7.10), now in the museum of Capodimonte, seems to have drawn upon existing images of King Robert. If its attribution to the workshop of Tino di Camaino and its connection to the monuments he made in 1333 for Charles I and Charles II in the cathedral are correct, ${ }^{53}$ this similitude would indicate a migration of

53 Naples, Museum of Capodimonte, $33 \times 40 \times 26 \mathrm{~cm}$. Its date and attribution have been subject to different interpretations. When Charles I died in 1285 , his body was transferred from Foggia to Naples, where he was buried in a marble monument (a tomb slab?) in the old cathedral. Some years later, Charles Martel (1271-1295), King of Hungary, and his wife, Clemence of Habsburg (1262-1295), were also buried in the old cathedral. Enderlein, Die Grablegen, pp. 135-36, 199, figs. 95-97. He attributes the head to the workshop of Tino da Camaino and dates it, on stylistic grounds, to the 1330s. He proposes its identification as Charles I (1266-1285), relating it to his new, honorary funeral monument, installed in the cathedral in 1338. Moreover, Enderlein suggests its attribution to Tino da Camaino by comparing the crown to the gisant of Maria of Anjou and its facial traits with the monument to Robert the Wise in Santa Chiara. The correspondence between the heads of the two monuments is even more telling, given that the honorific tomb of Charles I featured a figure of the king in majesty and seems, therefore, to could have been the iconographic model for the elaborate monument to Robert sculpted only a few years later, in 1345 . Enderlein, however, does not exclude the possibility that the head once belonged to the tomb of Philip of Taranto (1278-1331) in San Domenico Maggiore, of which only a few fragments survive today. See also: Paola Giusti, "I resti di una sepoltura regale angioina," in Scritti di storia dell'arte in memoria di Raffaello Causa, ed. Pierluigi Leone di Castris (Naples, 1988), pp. 39-44; Michalsky, Memoria und Repräsentation, p. 254 (with previous bibliography); Paola Giusti, "Scultore francese attivo presso la corte angioina, c. 1300," in Ori, argenti, gemme e smalti della napoli angioina 1266-1381. Exhibition catalogue Naples, Cappella and Museo del Tesoro di San Gennaro, 11 October-31 December 2014, ed. Pierluigi Leone de Castris (Naples, 2014), pp. 86-89 (with an incomplete bibliography and without discussion of previous or diverging research in her catalogue entry). She proposes an earlier date of $c .1300$ and attributes the head to an unknown French sculptor. As reference works, she cites sculptures from Reims from the beginning of the 13th century. She then proposes the gisants of Philip III († 1295) by Jean d'Arras, $c .1298$, and of his successors Louis X (1305-1316), Philip v (1316-1322), and Charles Iv le Bel (1322-1328) in SaintDenis as French precursors in funeral portraiture. She suggests a direct derivation of the Neapolitan head from the reliquary bust of San Gennaro, made by four French goldsmiths in 1304-05. The catalogue entry concerning the effigies of Philip III by François Baron points, however, in a different direction refuting the idea of naturalistic portraiture: "Cat. no. 28: Philippe III, roi de France (†1285)," in L'art au temps des rois maudits. Philippe le Bel et ses fils 1285-1328. Exhibition catalogue Paris, Grand Palais, 17 mars-29 juin 1998 (Paris, 1998), pp. 72-73. "Ce point de vue, soutenu notamment par A. Erlande Brandenburg, écarte bien entendu toute idée de portrait et rattache le visage du roi à la tradition idéaliste renouvelée par une certaine volonté d'individualisation." On the complex state of 
facial features from the living king to his deceased ancestors, with one king's personalized traits - pointing back to Pietro d'Abano, one could speak here of dispositio - becoming a go-to type for others.

Portraiture was not Simone's invention, and its rhetoric had existed before. For instance, in 1281-1284, Arnolfo sculpted a majestic statue of Charles I as a Roman senator for the tribuna of the Aracoeli in Rome. Research has addressed its relationship to antiquity, to the tradition of honorary statues, and to Hohenstaufen imagery, especially the portrait busts of Frederick II. In the same period, around 1300, sculptures of Pope Boniface viII with personalized features were installed in various places, and the pope's portrait bust even adorned the funeral monument he had created during his lifetime. Not all of these images had what we would deem a portrait quality, but they all visually represented the pope and his authority using individualizing features. Among others, Monika Butzek, Agostino Paravicini, and Etienne Anheim have traced the history of papal statues and have presented written sources attesting to an ample use of portraits in the second half of the 13th century, especially in works of goldsmithery. ${ }^{54}$ Most of these works have been lost; what remains is

the research concerning bust reliquaries and on the problems related to portraiture, see: Barbara Drake Boehm, "Body-part reliquaries; the state of research," Gesta 36 (1997), 8-19. Beate Fricke, "Entlarvende Gesichter. Gedanken zur Genese der Kopfreliquiare in Italien", Kopf / Bild. Die Büste in Mittelalter und früher Neuzeit, eds. Jeanette Kohl and Rebecca Müller (Munich, Berlin 2007), pp. 133-52. For the royal burials in Naples cathedral, see: Vinni Lucherini, "La Cappella di San Ludovico nella Cattedrale di Napoli, le sepolture dei sovrani angioini, le due statue dei re e gli errori della tradizione storiografica moderna," Zeitschrift für Kunstgeschichte 70 (2007), 1-22; Vinni Lucherini, La cattedrale di Napoli. Storia, architettura, storiografia di un monumento medievale (Rome, 20o9); Maria Alasia Lombardo di Cumia, La topografia artistica del Duomo di Napoli (Naples 2011), pp. 136-154.Vinni Lucherini, "Precisazioni documentarie e nuove proposte sulla commissione e l'allestimento delle tombe reali angioine nella cattedrale di Napoli," in L'officina dello sguardo. Scritti in onore di Maria Andaloro, eds. Giulia Bordi, Iole Carlettini, Maria Luigia Fobelli, Maria Raffaella Menna, and Paola Pogliani (Rome, 2014), pp. 185-92.

54 Monika Butzek, Die kommunalen Repräsentationsstatuen der Päpste des 16. Jahrhunderts in Bologna, Perugia und Rom (Bad Honnef, 1978); Nancy Rash, "Boniface VIII and Honorific Portraiture: Observations on the Half-Length Image in the Vatican," Gesta 26 (1987), 4758; Georgia Sommers Wright, "The Reinvention of the Portrait Likeness in the Fourteenth Century," Robert Branner and the Gothic. Gesta 39/2 (2000), 117-34; Agostino Paravicini Bagliani, "Il busto di Bonifacio viri. Nuove testimonianze e una rilettura," in Arnolfo di Cambio e la sua epoca, ed. Vittorio Franchetti Pardo (Rome, 20o6), pp. 189-96; Etienne Anheim, "I ritratti dei papi tra Roma e Avignone," in Arnolfo di Cambio, ed. Franchetti Pardo, pp. 231-38; Agostino Paravicini Bagliani, "Les portraits de Boniface VIII: une tentative de synthèse," in Le portrait. La représentation de l'individu, ed. Agostino Paravicini Bagliani (Florence, 2007), pp. 117-39; Agostino Paravicini Bagliani, "Boniface VIII en images. Vision d'Eglise et mémoire de soi," in Le portrait individuel. Réflexions autour d'une 
only a shadow of a much bigger tradition, of which the most valuable pieces have been melted down. Some of them, however, present very individualized faces and fulfil many of the criteria of portraiture.

It is interesting that Naples, like Rome, Assisi, and Avignon, seems to have provided a fertile ground for the development of portraiture. ${ }^{55}$ In 1320 , that is, only a few years after Simone's Saint Louis Altarpiece, Lello d'Orvieto painted a portrait of Umberto d'Ormont for his funeral monument (Figure. 7.11). ${ }^{56}$ Serena Romano has shown that its direct precursors lay in the tradition of the early Christian portraits of Neapolitan bishops. ${ }^{57}$ The chronological proximity between these two major examples of portraiture in European painting indicates a strong taste for individualizing images among the Neapolitan elite.

The question of who was actually in charge of the Saint Louis Altarpiece and who collaborated with Simone on its programme is difficult to answer. Various members of the Angevin family have been proposed as its possible patrons - King Robert, his wife Sancia, his mother Mary of Hungary, and his brother Philip of Taranto - along with the Franciscan convent of San Lorenzo Maggiore. ${ }^{58}$ The elaboration of the complex programme certainly required the participation of knowledgeable theologians and high-ranking, learned

forme de représentation XIIIe-XVe siècles, ed. Dominic Olariu (Bern, 2009), pp. 83-102. For the lost portrait of Cardinal Napoleone Orsini by Simone Martini, given to Pope Clement VI (1342-52), see: Andrew Martindale, Simone Martini (Oxford, 1989), pp. 49-5o. On the portrait of Clement v (1305-14) given to Giotto, see: Vasari, Le Vite, p. 119. On funeral portraits on tomb monuments of the Curia see Julian Gardner, The tomb and the Tiara. Curial tomb sculpture in Rome and Avignon in the Later Middle Ages (Oxford, 1992), Appendix "Tombs and portraiture", pp. 172-175.

55 The question raised implicitly by: Enrico Castelnuovo, "Propter quid imagines faciei faciunt," pp. 33-50, on whether certain places are more fertile for portraiture than others, is of course not limited to Naples, Rome, or Avignon but could be raised for cities and courts as well. In Verona, for instance, the triumphal arch of San Fermo was decorated in 1314 with portraits of Fra Gusmeno and Guglielmo da Castelbono.

56 Bologna, I pittori, pp. 116-32; Pierluigi Leone de Castris, Arte di corte nella Napoli angioina (Florence, 1986), p. 267; Ferdinando Bologna, "Una aggiunta a Lello da Orvieto," in Scritti di storia dell'arte in onore di Raffaello Causa, ed. Pierluigi Leone de Castris (Naples, 1988), pp. 47-52; Vinni Lucherini, "1313-1320: il cosiddetto Lello da Orvieto, mosaicista e pittore, a Napoli, tra committenza episcopale e committenza canonicale," in El Trecento en obres. Art de Catalunya i art d'Europa al segle XIV, ed. Rosa Alcoy (Barcelona, 2009), pp. 185-215.

57 Serena Romano, "Introduzione: la cattedrale di Napoli, i vescovi e l'immagine. Una storia di lunga durata," in Il Duomo di Napoli, dal paleocristiano all'età angioina, eds. Serena Romano, and Nicolas Bock (Naples, 2002), pp. 7-20.

$5^{8}$ The most recent discussion by Norman, Siena and the Angevins, pp. 133-147. The proposal of the Franciscan commission by Aceto, "Spazio ecclesiale," 2-50. 
officials. ${ }^{59}$ Patronage must therefore be seen more as a network. ${ }^{60}$ Taking up Stephen Perkinson's dictum that "the portrait depicts the person for whom the object was made," one must note the role of King Robert of Anjou in the commission. ${ }^{61}$ Already in January 1300, only two and a half years after Louis's death, Robert had been part of the small group of men whom King Charles II charged with launching his brother's canonization. ${ }^{62}$ Robert followed the process closely, acting as the individual most deeply involved.

The fact that the Angevins around Robert of Anjou, along with their intellectual and administrative entourage, rapidly developed a strategy for assuring visual presence using all the artistic means available is indicative of a larger marked sensibility for portraiture at the Neapolitan court. One might recall that, when Robert became signore of Florence in 1310, a full-length image of him was placed on the façade of the Palazzo di Parte Guelfa. ${ }^{63}$ Since the painting is lost today, it is impossible to determine whether it showed any life-like traits. Further proof of the general taste for individualized facial features in Neopolitan art can be seen in the tomb slab of Fra Donato, made in 1308 on the occasion of his translation to the church of San Lorenzo Maggiore (Figure. 7.12) ${ }^{64}$ Here, the image could not have been made from life, the saint having

59 One might think here of important personalities such as Bartolomeo da Capua (12481328), protonotario and logotheta who was crucial in defining the political principles of the kingdom. The inscription on his tomb even named him summus atleta regni. Ingeborg Walter, and Maura Piccialuti, "Bartholomeo da Capua," in Dizionario biografico degli italiani 6 (Rome, 1964), pp. 697-704; Andreas Kiesewetter, Die Anfänge der Regierung Karls II. von Anjou (1278-1295): das Königreich Neapel, die Grafschaft Provence und der Mittelmeerraum zu Anfang des 13. Jahrhunderts (Husum, 1999), pp. 420-23.

6o Perkinson "Portraits \& their Patrons," 253-4, referred to questions of agency as formulated by Harry Berger, Jr, and Alfred Gell when he stated that "we might think of 'patronage' as being less discrete, and more like a network."

61 Perkinson "Portraits \& their Patrons," 248.

62 The group consisted of a royal procurator, the Provençal archbishops and their suffragans, as well as the city of Marseille. Brunner, "Poverty and Charity," 234. Only in 1307 did Pope Clement $\mathrm{v}$ appoint the official delegation that was to investigate Louis's sanctity.

63 Norman, Siena and the Angevins, pp. 26, 38, n. 49. An attribution of this now-lost painting to Giotto was proposed by: Lucia Battaglia Ricci, Palazzo Vecchio e dintorni. Studio su Franco Sacchetti e le fabbriche di Firenze (Rome, 1990), pp. 71-77. For Giotto's painting of Charles of Calabria, in front of the Virgin in the Palazzo Vecchio, see: Nicolai Rubinstein, The Palazzo Vecchio, 1298-1532. Government, architecture, and Imagery in the Civic Palace of the Florentine Republic (Oxford, 1995), pp. 47-48.

64 On Fra Donato, see: P. Giovanni Recupido, Il beato Donato sepolto in San Lorenzo Maggiore di Napoli (Naples, 1972). On the monument: Shirley F. Bridges and John Bryan WardPerkins, "Some 14th century Neapolitan military effigies - with notes on the families represented," Papers of the British School at Rome 24, n.s. 11, Studies in Italian medieval history, presented to E. M. Jamison (1956), 158-73; Sculture trecentesche in S. Lorenzo Maggiore a 
been long deceased; the impressive traits of his face are pure invention. The same is true for the magnificent reliquary bust of San Gennaro, made by French goldsmiths in 1304/05. ${ }^{65}$ These examples speak to an ideal of individual sanctity that reaches back at least to the Romanesque period and clearly runs counter to the idealization Simone applied to Saint Louis's face in his Neapolitan altarpiece. ${ }^{66}$ And although we cannot count them as direct ancestors of Simone's portrait of Robert of Anjou, this type of image seems to have been very much appreciated in Naples at the beginning of the 14th century and to have contributed to the desire for and production of individualized images. ${ }^{67}$

Napoli, ed. Raffaele Mormone (Naples, 1973), pp. 33-34, n. 8, fig. 18; Frank Allen Greenhill, Incised effigial slabs. A study of engraved stone memorials in Latin Christendom, c. 1100 to c. 1700, 2 vols (London, 1976), fig. 29c; Nicolas Bock, "Des dalles et des modèles. Les origines françaises de la sculpture funéraire napolitaine," in Les modèles dans l'art du Moyen Âge (XIIe-XVe siècles)/Models in the Art of the Middles Ages (12th-15th centuries), eds. Denise Borlée, and Laurence Terrier Alfieris (Turnhout, 2018), pp. 85-96. The inscription reads as follows: + ANNO D(omi)NI MILL(en)O / CCC OCTAVO IN D(omi)NICA DE LETARE IERUSALEM TRANSLATUM EST HUC / CORPUS F(rat)RIS DONATI VIRI S(an)C(t)I / PRO QUO MULTA OSTENDIT DEUS MIRACULA IN VITA SUA SICUT EX/PERTI TESTANT.

65 See the latest publication by: Pierluigi Leone de Castris, "Maestro Etienne, Godefroy, Milet d'Auxerre, Guillaume de Verdelay, 1304-05. Busto reliquiario di San Gennaro," in Ori, argenti, gemme e smalti, ed. de Castris, pp. 76-85 (with bibliography).

66 A good example of previous individualizing tendencies in the genre of reliquary busts and of the problems inherent to drawing straight lines of development for portraiture - is the silver casing of the bust reliquary of Saint Yrieix from the 12th century, New York, Metropolitan Museum of Art, showing the stubbles of a badly shaven beard. Drake Boehm, "Body-part reliquaries," p. 12, fig. 6. Fricke, "Entlarvende Gesichter", pp. 146-47, n. 29 proposes to link the growing need for facial characterization in art during the 13th century to contemporary physiognomic treatises. She refers to the negative connotation of wrinkle-free faces given by Michael Scotus: "frons plana pelle et non continens rugas hominem ex facili ligitantem: vanum, fallacem, plus simplicem quam sapientem." For the Scotus' treaty see Sauerländer, "Phisionomia est doctrina salutis", p. 101, n. 2.

67 This trend is not limited to the Kingdom of Naples. The royal image became generally more personalized around 1300, be it in the Holy Roman Empire or in the Kingdom of France. The funeral images of Emperor Rudolf of Habsburg ( $†$ 1291) in Speyer and of King Philip III the Bold († 1285) in Saint-Denis each show a number of marked facial traits, distinguishing them from prior images. Julian Gardner, "Stone Saints: Commemoration and likeness in thirteenth century Italy, France and Spain," Contemporary Approaches to the Medieval Face. Gesta 46/2 (2007), 121-34. For the genesis of these portraits and some hypotheses concerning their connection to early 13th-century cathedral sculpture, see: Martin Büchsel, "Nur der Tyrann hat sein eigenes Gesicht. Königsbilder im 12. und 13. Jahrhundert in Frankreich und Deutschland," in Das Porträt, eds. Büchsel et al., pp. 123-40; Tanja Praske, Ludwig IX. der Heilige - eine Zäsur für die monumentale französische Königsdarstellung. Bildkonzepte der Zeit Philipps IV., PhD thesis (Frankfurt am Main, 2015). In this context, one must also consider the close ties of the Neapolitan court 
In their portrayals of Robert of Anjou, Simone Martini and Tino di Camaino provide exemplary case studies for reflecting upon the question of royal portraiture around 1300. Several points have emerged. First of all, on the question of chronology: it is evident that naturalism did not increase within a clear evolution resulting in a 'birth of portraiture.' Tino di Camaino worked on his royal representations 10 years after Simone and Arnolfo 20 years before; each adhered to different stylistic currents and models, yet all combined individualizing and stereotyping elements in their work. The question of individualized traits was therefore not dependent upon the artistic medium and did not adhere to any precise chronology between 128 o and 1330 . The option to render a person using either individualized or stereotyped traits coexisted throughout.

The cases explored in this essay also call into question the assumption that similitudo, in the sense of naturalism, represented the main criterion for identification during the period in question: the identifiability of a person did not necessarily increase with greater naturalism. ${ }^{68}$ Rather, the selected 'mode' of representation was geared towards emphasizing the role of the depicted individual in society. ${ }^{69}$ This could be achieved either through idealization (in the sense of a purposeful distinguishing from others) or through individualization, i.e. the accumulation of discrete physiognomic characteristics with the aim of creating visual difference. ${ }^{70}$ Simone's naturalistic rendering of Robert's face can only be understood in relation to the idealization of Louis' traits - both are interdependent of each other. Around 1300, the public knew how to approach both artistic forms, the schematic and the naturalistic, and could even joke

to the papal curia. See Wright, "The Reinvention of the Portrait Likeness," 119-23 who discusses the eleven known portraits ("ad similitudinem ipsius sanctissimi patris") of Pope Boniface viII.

68 Stephen Perkinson, "Rethinking the Origins of Portraiture," Contemporary Approaches to the Medieval Face. Gesta 46/2 (2007), 135-57. See also, most recently, the overview with bibliography by: Michele Tomasi, "Il ritratto nel medioevo: una cornice," in Intorno al ritratto. Origini, sviluppi e trasformazioni. Studi a margine del saggio di Enrico Castelnuovo, Il significato del ritratto pittorico nella società (1973), eds. Fabrizio Crivello, and Laura Zamparo (Turin, 2019), pp. 83-92.

69 Enrico Castelnuovo, "Il significato del ritratto pittorico nella società," in Storia d'Italia 2, I documenti (Turin, 1973), pp. 1031-94.

70 The idealization of Saint Louis' angelical appearance and the mimetic rendering of Robert's face are interdependant modes of representation which refer to each other. 
about it: in 1306, during a trial over an attempted act of witchcraft against Cardinal Gaetani, the wax image used for the supposed act was presented to the cardinal. Looking at it, he burst out laughing and mocked its failed attempt at naturalism:

We modelled a puppet [image] and showed it to the cardinal [Gaetani], and he started to laugh and was very much amused, and he told them: it has really big arms and legs, absolutely perfect and strong. ${ }^{71}$

Simone's trajectory, finally, shows the general importance of the artist to the creation of a portrait. Or to put it more bluntly: there is no portrait without an artist. Of all the artists around 1300, it was Simone who pushed individualization to new artistic limits. If his Saint Louis Altarpiece represents an important artistic refinement of portraiture, his works from the same period in Assisi show how he experimented with the use of individualizing features even when representing historic persons he had never met. He thus created not only mock portraits but, moreover, implicitly reflected on the possibilities of portraiture as an artistic and rhetorical genre. The Angevin royal portrait he executed for the Saint Louis Altarpiece in 1317 was part of this process of deliberation on the limits of personal presence in painting. Portraiture around 1300 had become a question of rhetoric and, as such, a matter of modes.

\section{Acknowledgements}

For discussing with me the problems of portraiture, I would like to thank Damien Cerutti, Ana Marinkovic, and Michele Tomasi.

71 "Nous avons fait une ymage et le monstrames au cardinal [Gaetani] et il commencha à rir et ut trop grant ioie et leur dist: il a moult grant membre, parfaits bien et tost." Keller, "Die Entstehung des Bildnisses," 287. A similar irony concerning the search for naturalistic portrait likeness is expressed by the poet Ottokar when he mocks the sculptor (kluoger steinmetze) responsible for the tomb monument of Rudolph of Habsburg († 1291), who had not only counted the wrinkles in the king's face but also, when he heard about a new wrinkle, rode back from Speyer to Alsace to update the effigy. "Ottokars österreichische Reimchronik," in Monumenta Germaniae historica, Deutsche Chroniken, ed. Joseph Seemüller (Hannover, 189o), vol. v.1, 508-9, lines 39125-94. Wright, "The Reinvention of the Portrait Likeness," 118. Paul Binski, "The early portrait: verbal or pictorial?", in Europäische Kunst um 1300. Akten des XXV. Internationalen Kongresses für Kunstgeschichte, Wien, 4. -10. September 1983 (Vienna 1986), pp. 211-15. 


\section{Bibliography}

\section{Primary Sources}

Convenevole da Prato, Regia carmina, ed. and trans. Cesare Grassi (Cinisello Balsamo, 1982).

Giorgio Vasari, Le vite de' piu eccellenti pittori, scultori e architettori, nelle redazioni del 1550 e 1568 2, eds. Rosanna Bettarini, and Paola Barocchi (Florence 1967-).

Giovanni Villani, Nuova Cronica, ed. Giuseppe Porta, 3 vols (Parma, 1990-91).

"Historiae Romanae fragmenta ab anno MCCCXXVII usque ad MCCCLIX," in Antiquitates italicae medii aevi, ed. Lodovico Antonio Muratori (Milan, 1738-42), vol. III, col. 307-09.

"Ottokars österreichische Reimchronik," in Monumenta Germaniae historica, Deutsche Chroniken, ed. Joseph Seemüller (Hannover, 189o), vol. v.1-2.

Processus canonizationis et legendae variae Sancti Ludovici O.F.M. episcopi Tolosani, ed. Collegium Sanctae Bonaventurae (Quaracchi, 1951).

\section{Secondary Sources}

IV Mostra di restauri: catalogo, ed. Soprintendenza delle Gallerie della Campania Laboratorio di Conservazione (Naples 1960).

Aceto, Francesco, "Tino di Camaino a Napoli: una proposta per il sepolcro di Caterina d'Austria e altri fatti angioini," Dialoghi di storia dell'arte 1 (1995), 10-27.

Aceto, Francesco, "Spazio ecclesiale e pale di 'primitivi' in San Lorenzo Maggiore a Napoli: dal 'San Ludovico' di Simone Martini al 'San Girolamo' di Colantonio," Prospettiva 137 (2010), 2-50.

Aceto, Francesco, "Per Simone Martini pittore: ancora sull'iconografia del 'San Ludovico' del Museo di Capodimonte a Napoli," in Da Ludovico d'Angiò a san Ludovico di Tolosa. I testi e le immagini. Atti del Convegno internazionale di studio per il VII centenario della canonizzazione (1317-2017), Napoli - S. Maria Capua Vetere, 3-5 novembre 2016, eds. Teresa D’Urso, Alessandra Perriccioli Saggese, and Daniele Solvi (Spoleto, 2017), pp. 33-5o.

Anheim, Etienne, "I ritratti dei papi tra Roma e Avignone," in Arnolfo di Cambio e la sua epoca, ed. Vittorio Franchetti Pardo (Rome, 2006), pp. 231-38.

Bagnoli, Alessandro, "I tempi della ,Maesta.' Il restauro e le nuove evidenze," in Simone Martini, ed. Luciano Bellosi (Florence, 1988), pp. 109-18.

Bagnoli, Alessandro, La Maestà di Simone Martini (Cinisello Balsamo, 1999).

Barbero, Alessandro, "La propaganda di Roberto d'Angiò re di Napoli (1309-1343)," in Le forme della propaganda politica nel Due e Trecento. Atti del convegno internazionale, Trieste, 2-5 marzo 1993, ed. Paolo Cammarosano (Rome, 1994), pp. 111-31.

Baron, François, “Cat. no. 28: Philippe III, roi de France († 1285)," in L'art au temps des rois maudits. Philippe le Bel et ses fils 1285-1328. Exhibition catalogue Paris, Grand Palais, 17 mars - 29juin 1998 (Paris, 1998), pp. 72-73. 
Battaglia Ricci, Lucia, Palazzo Vecchio e dintorni. Studio su Franco Sacchetti e le fabbriche di Firenze (Rome, 1990).

Bauch, Kurt, "Giotto und die Porträtkunst," in Giotto e il suo tempo. Atti del Congresso internazionale per la celebrazione del VII centenario della nascita di Giotto, 24 settembre-1 ottobre 1967, (Assisi, 1971), pp. 299-309.

Bedos-Rezak, Brigitte-Myriam, When ego was imago. Signs of Identity in the Middle Ages (Leiden, 2011).

Bellosi, Luciano, "La barba di San Francesco (nuove proposte per il 'problema di Assisi')," Prospettiva 121/124 (2006), 143-65 (originally published in: Prospettiva 22 (1980), 11-34).

Bellosi, Luciano, "Moda e cronologia. A) La decorazione della basilica inferiore di Assisi," Prospettiva 121/124 (2006), 428-437 (originally published in: Prospettiva 10 (1977), 21-31).

Bellosi, Luciano, “Il 'pittore oltremontano' di Assisi, il Gotico a Siena e la formazione di Simone Martini," Prospettiva 121/124 (2006), 227-36 (originally published in: Simone Martini, Atti del convegno, Siena 1985, ed. Luciano Bellosi (Florence, 1988), pp. 39-47).

Belting, Hans, "Wappen und Porträt. Zwei Bildmedien des Körpers," in Das Porträt vor der Erfindung des Porträts, eds. Martin Büchsel, and Peter Schmid (Mainz, 2003), pp. 89-100.

Binski, Paul, "The early portrait: verbal or pictorial?", in Europäische Kunst um 1300. Akten des XXV. Internationalen Kongresses für Kunstgeschichte, Wien, 4. -10. September 1983 (Vienna 1986), pp. 211-15.

Bock, Nicolas, Kunst am Hofe der Anjou-Durazzo. Der Bildhauer Antonio Baboccio (1351um 1423) (Berlin, 2001).

Bock, Nicolas, "L'Ordre du Saint-Esprit au Droit Désir. Enluminure, cérémonial et idéologie au $14^{\mathrm{e}}$ siècle," in Art, cérémonial et liturgie au Moyen Age, eds. Nicolas Bock, Peter Kurmann, Serena Romano, and Jean-Michel Spieser (Rome, 2002), pp. 415-61.

Bock, Nicolas, "La visione del potere. Cristo, il re e la corte angioina," in Cristo e il potere. Teologia, antropologia e politica, eds. Laura Andreani, and Agostino Paravicini Bagliani (Florence, 2017) pp. 211-24.

Bock, Nicolas, "Des dalles et des modèles. Les origines françaises de la sculpture funéraire napolitaine," in Les modèles dans l'art du Moyen Âge (XIIe-XVe siècles)/ Models in the Art of the Middles Ages (12th-15th centuries), eds. Denise Borlée, and Laurence Terrier Alfieris (Turnhout, 2018), pp. 85-96.

Boehm, Barbara Drake, “Body-part reliquaries; the state of research," Gesta 36 (1997), 8-19.

Bologna, Ferdinando, I pittori alla corte Angioina di Napoli (1266-1414) (Rome, 1969).

Bologna, Ferdinando, "Povertà e umiltà: il San Ludovico di Simone Martini," Studi storici 10 (1969), 231-59.

Bologna, Ferdinando, "Una aggiunta a Lello da Orvieto," in Scritti di storia dell'arte in onore di Raffaello Causa, ed. Pierluigi Leone de Castris (Naples, 1988), pp. 47-52. 
Bologna, Ferdinando, "La canonizzazione di san Ludovico di Tolosa e l'origine assisiate dell'ancona napoletana di Simone Martini," in Modelli di lettura iconografica. Il panorama meridionale, ed. Mario Alberto Pavone (Naples, 1999), pp. 17-48.

Bräm, Andreas, Neapolitanische Bilderbibeln des Trecento, 2 vol. (Wiesbaden, 2007).

Bridges, Shirley F. and Ward-Perkins, John Bryan, "Some 14th century Neapolitan military effigies - with notes on the families represented," Papers of the British School at Rome 24, n.s. 11, Studies in Italian medieval history, presented to E. M. Jamison (1956), 158-73.

Brunel, Ghislain, Images du pouvoir royal. Les chartes décorées des Archives nationales, $X I I{ }^{e}-X V^{e}$ siècle (Paris, 2005).

Brunner, Melanie, "Poverty and Charity: Pope John XXII and the Canonization of Louis of Anjou," Franciscan Studies 69 (2011), 231-256.

Büchsel, Martin, "Nur der Tyrann hat sein eigenes Gesicht. Königsbilder im 12. und 13. Jahrhundert in Frankreich und Deutschland," in Das Porträt vor der Erfindung des Porträts, eds. Martin Büchsel, and Peter Schmid (Mainz, 2003), pp. 123-40.

Büchsel, Martin, "Le portrait au Moyen Âge," Perspective 2 (2012), 401-o6.

Burckhardt, Jacob, "Das Porträt in der Malerei," in Jacob Burckhardt Werke. Das Altarbild. Das Porträt in der Malerei. Die Sammler. Beiträge zur Kunstgeschichte von Italien 6, eds. Stella van Boch, Johannes Hartau, Kerstin HengevossDürkop, and Martin Warnke (Munich, Basel, 200o), pp. 140-281.

Butzek, Monika, Die kommunalen Repräsentationsstatuen der Päpste des 16. Jahrhunderts in Bologna, Perugia und Rom (Bad Honnef, 1978).

Caldi, Louise, The King and His Brother. Simone Martini's Louis of Toulouse Crowning Robert of Anjou and the Visual Language of Power, PhD thesis (Rutgers, State University of New York, 2002).

Cassidy, Brendan, "An image of King Robert of Naples in a Franco-Italian manuscript in Dublin," Burlington Magazine 148 (2006), 31-33.

Cassidy, Brendan, "Simone Martini's 'St Martin and the Emperor' and contemporary Italian politics," Zeitschrift für Kunstgeschichte 70 (2007), 145-58.

Castelnuovo, Enrico, "Il significato del ritratto pittorico nella società," in Storia d'Italia 2, I documenti (Turin, 1973), pp. 1031-94.

Castelnuovo, Enrico, “'Propter quid imagines faciei faciunt.' Aspetti del ritratto pittorico nel Trecento," in Le metamorfosi del ritratto, ed. Renzo Zorzi (Florence, 2002), pp. $33-5$ o.

Castelnuovo, Enrico, "Les portraits individuels de Giotto," in Le portrait individual. Réflexions autour d'une forme de representation XIIIe-XVe siècles, ed. Dominic Olariu (Bern, 2009), pp. 103-20.

Chelazzi Dini, Giulietta, Pacio e Giovanni Bertini da Firenze e la bottega napoletana di Tino di Camaino (Florence, 1996).

Claussen, Peter Cornelius, "Die Statue Friedrichs II. vom Brückentor in Capua (12341239): der Befund, die Quellen und eine Zeichnung aus dem Nachlaß von Seroux 
d'Agincourt," in Festschrift für Hartmut Biermann, eds. Christoph Andreas, Mareike Bückling, and Roland Dorn (Weinheim, 1990), pp. 19-39, 291-304.

Claussen, Peter Cornelius, "Stauferbilder - Bildnisse der Staufer," in Verwandlungen des Stauferreichs, eds. Bernd Schneidmüller, Stefan Weinfurter, and Alfred Wieczorek (Darmstadt, 2010), pp. 350-76.

Collareta, Marco, "Modi di presentarsi: taglio e visuale nella ritrattistica autonoma," in Visuelle Topoi. Erfindung und tradiertes Wissen in den Künsten der italienischen Renaissance, eds. Ulrich Pfisterer, and Max Seidel (München, 2003), pp. 131-49.

De Rinaldis, Aldo, “La tomba primitiva di Roberto d'Angiò," Belvedere 5 (1924), pp. $92-96$.

Di Fabio, Clario, "Memoria e modernità: della propria figura di Enrico Scrovegni e di altre sculture nella cappella dell'Arena di Padova, con aggiunte al catalogo di Marco Romano," in Medioevo: immagine e memoria, ed. Arturo C. Quintavalle (Milan, 2009), pp. 532-46.

Dombrowski, Damian, “'Cernite' - Vision und Person am Grabmal Roberts des Weisen in S. Chiara," in Praemium Virtutis. Grabmonumente und Begräbniszeremoniell im Zeichen des Humanismus, eds. Joachim Poeschke, and Britta Kusch (Münster, 2002), pp. 35-6o (repr. in Der Tod und die Künste, eds. Friederike Felicitas Günther, and Wolfgang Riedel (Würzburg, 2016), pp. 49-99).

Donato, Maria Monica, "Transetto settentrionale. Simone Martini," in La Basilica de San Francesco d'Assisi. Basilica inferiore/The Basilica of St Francis in Assisi. Lower Basilica, ed. Giorgio Bonsanti (Modena, 2002), n. 150-6o, pp. 424-26, 554-56o.

D’Ovidio, Stefano, “Cernite Robertum Regem Virtute Refertum: la 'fortuna' del monumento sepolcrale di Roberto d'Angiò in S. Chiara," in La chiesa e il convento di Santa Chiara. Committenza artistica, vita religiosa e progettualità politica nella Napoli di Roberto d'Angiò e Sancia di Maiorca, eds. Francesco Aceto, Stefano D'Ovidio, and Elisabetta Scirocco (Battipaglia, 2014), pp. 275-312.

D’Ovidio, Stefano, “Osservazioni sulla struttura e l'iconografia della tomba di re Roberto d'Angiò in Santa Chiara a Napoli," Hortus artium medievalium 21 (2015), 92-112.

Duran, Michelle M., "The politics of art: imaging sovereignty in the Anjou Bible," in The Anjou Bible. A royal Manuscript revealed. Naples 1340, eds. Lieve Watteeuw, and Jan van der Stock (Paris, 2010), pp. 73-93.

Enderlein, Lorenz, "Zur Entstehung der Ludwigstafel des Simone Martini," Römisches Jahrbuch der Bibliotheca Hertziana 30 (1995), 135-49.

Enderlein, Lorenz, Die Grablegen des Hauses Anjou in Unteritalien. Totenkult und Monumente 1266-1343 (Worms, 1999).

Fricke, Beate, "Entlarvende Gesichter. Gedanken zur Genese der Kopfreliquiare in Italien", Kopf / Bild. Die Büste in Mittelalter und früher Neuzeit, eds. Jeanette Kohl, and Rebecca Müller (Munich, Berlin 2007), pp. 133-52.

Frugoni, Chiara, Francesco e l'invenzione delle stimmate (Turin, 1993). 
Frugoni, Chiara, “Ambrogio Lorenzetti," in Pietro e Ambrogio Lorenzetti, ed. Chiara Frugoni (Florence, 2002), pp. 119-99.

Gaglione, Mario, Nuovi studi sulla Basilica di Santa Chiara (Naples, 1996).

Gaglione, Mario, "Il San Ludovico di Simone Martini: manifesto della santità regale angioina," Rassegna storica salernitana 58 (2012), 9-125.

Gardner, Julian, "Saint Louis of Toulouse, Robert of Anjou, and Simone Martini," Zeitschrift für Kunstgeschichte 39 (1976), 12-33.

Gardner, Julian, "A Princess among prelates: a fourteenth century Neapolitan tomb and some northern relations," Römisches Jahrbuch für Kunstgeschichte 23/24 (1988), 29-6o.

Gardner, Julian, The Tomb and the Tiara. Curial Tomb Sculpture in Rome and Avignon in the Later Middle Ages (Oxford, 1992).

Gardner, Julian, "Stone Saints: Commemoration and likeness in thirteenth century Italy, France and Spain," Contemporary Approaches to the Medieval Face. Gesta 46/ 2 (2007), 121-34.

Giusti, Paola, "I resti di una sepoltura regale angioina," in Scritti di storia dell'arte in memoria di Raffaello Causa, ed. Pierluigi Leone di Castris (Naples, 1988), pp. 39-44.

Giusti, Paola, "Scultore francese attivo presso la corte angioina, c. 1300," in Ori, argenti, gemme e smalti della napoli angioina 1266-1381. Exhibition catalogue Naples, Cappella and Museo del Tesoro di San Gennaro, 11 October-31 December 2014, ed. Pierluigi Leone de Castris (Naples, 2014), pp. 86-89.

Greenhill, Frank Allen, Incised effigial slabs. A study of engraved stone memorials in Latin Christendom, c. 1100 to c. 170o, 2 vols (London, 1976).

Hall, Edwin, and Uhr, Horst, "Aureola and Fructus. Distinctions of Beatitude in Scholastic Thought and the Meaning of Some Crowns in Early Flemish Painting," Art Bulletin 6o (1978), 249-70.

Hall, Edwin, and Uhr, Horst, "Aureola super Auream. Crowns and Related Symbols of Special Distinction in Late Gothic and Renaissance Iconography," Art Bulletin 67 (1985), 567-6o3.

Hoch, Adrian S., "St. Martin of Tours: his transformation into a chivalric hero and Franciscan ideal," Zeitschrift für Kunstgeschichte 5o (1987), 471-82.

Hoch, Adrian S., "The Antique Origins of an Emperor by Simone Martini," Paragone 38 (1987), 42-47.

Hoch, Adrian S., "The Dedication of the St Elizabeth Altar at Assisi," Burlington Magazine 133/1054 (1991), 36-37.

Hoch, Adrian S., "Beata Stirps, royal patronage and the identification of the Sainted Rulers in the St. Elizabeth Chapel at Assisi," Art History 15 (1992), 279-95.

Hoch, Adrian S., "The Franciscan provenance of Simone Martini's Angevin St. Louis in Naples," Zeitschrift für Kunstgeschichte $5^{8}$ (1995), 22-38. 
Hueck, Irene, "Frühe Arbeiten des Simone Martini," Münchner Jahrbuch der bildenden Kunst 19 (1968), 29-6o.

Jackson, Richard A., "The Traité du sacre of Jean Golein," Proceedings of the American Philosophical Society 113 (1969), 305-24.

Keller, Harald, "Die Entstehung des Bildnisses am Ende des Hochmittelalters," Römisches Jahrbuch für Kunstgeschichte 3 (1939), 227-354.

Kelly, Samantha, The new Solomon. Robert of Naples (1309-1343) and fourteenth-century kingship (Leiden, 2003).

Kiesewetter, Andreas, Die Anfänge der Regierung Karls II. Von Anjou (1278-1295): das Königreich Neapel, die Grafschaft Provence und der Mittelmeerraum zu Anfang des 13. Jahrhunderts (Husum, 1999).

Kozlowski, Sarah, "Circulation, Convergence, and the Worlds of Trecento Panel Painting: Simone Martini in Naples," Zeitschrift für Kunstgeschichte 78 (2015), 205-38.

Krüger, Klaus, "A deo solo et a te regnum teneo. Simone Martinis, Ludwig von Toulouse' in Neapel," in Medien der Macht. Kunst zu Zeiten der Anjous in Italien, ed. Tanja Michalsky (Berlin, 2001), pp. 79-119.

Leone de Castris, Pierluigi, Arte di corte nella Napoli angioina (Florence, 1986).

Leone de Castris, Pierluigi, Simone Martini (Milano, 2003).

Leone de Castris, Pierluigi, "Maestro Etienne, Godefroy, Milet d'Auxerre, Guillaume de Verdelay, 1304-05. Busto reliquiario di San Gennaro," in Ori, argenti, gemme e smalti della napoli angioina 1266-1381. Exhibition catalogue Naples, Cappella and Museo del Tesoro di San Gennaro, 11 October-31 December 2014, ed. Pierluigi Leone de Castris (Naples, 2014), pp. 76-85.

Lombardo di Cumia, Maria Alasia, La topografia artistica del Duomo di Napoli dalla Fondazione angioina alla 'riforma' settecentesca del Cardinale Giuseppe Spinelli (Naples 2011).

Lucherini, Vinni, "La Cappella di San Ludovico nella Cattedrale di Napoli, le sepolture dei sovrani angioini, le due statue dei re e gli errori della tradizione storiografica moderna," Zeitschrift für Kunstgeschichte 70 (2007), 1-22.

Lucherini, Vinni, "1313-1320: il cosiddetto Lello da Orvieto, mosaicista e pittore, a Napoli, tra committenza episcopale e committenza canonicale," in El Trecento en obres. Art de Catalunya i art d'Europa al segle XIV, ed. Rosa Alcoy (Barcelona, 2009), pp. $185^{-215}$.

Lucherini, Vinni, La cattedrale di Napoli. Storia, architettura, storiografia di un monumento medievale (Rome, 2009).

Lucherini, Vinni, "Le tombe angioine nel presbiterio di Santa Chiara a Napoli e la politica funeraria di Roberto d'Angiò," in Medioevo. I committenti. Atti del convegno, Parma, 21-26 settembre 2010, ed. Arturo C. Quintavalle (Milan, 2011), pp. 477-504. 
Lucherini, Vinni, "Precisazioni documentarie e nuove proposte sulla commissione e l'allestimento delle tombe reali angioine nella cattedrale di Napoli," in L'officina dello sguardo. Scritti in onore di Maria Andaloro, eds. Giulia Bordi, Iole Carlettini, Maria Luigia Fobelli, Maria Raffaella Menna, and Paola Pogliani (Rome, 2014), pp. 185-92. Maginnis, Hayden, "The Passion Cycle in the Lower Church of San Francesco in Assisi: The Technical Evidence," Zeitschrift für Kunstgeschichte 39 (1976), 193-208.

Martindale, Andrew, Simone Martini (Oxford, 1989).

Michalsky, Tanja, "Die Repräsentation einer Beata Stirps: Darstellung und Ausdruck an den Grabmonumenten der Anjous," in Die Repräsentation der Gruppen. Texte, Bilder, Objekte, eds. Otto Gerhard Oexle, and Andrea von Hülsen Esch (Göttingen, 1998), pp. 187-224.

Michalsky, Tanja, Memoria und Repräsentation. Die Grabmäler des Königshauses Anjou in Italien (Göttingen, 2000).

Michalsky, Tanja, "MATER SERENISSIMI PRINCIPIS. The tomb of Maria of Hungary," in The Church of Santa Maria Donna Regina. Art, Iconography and Patronage in Fourteenth-Century Naples, eds. Janis Eliott, and Cordelia Warr (Aldershot, 2004), pp. $45^{-6 o}$.

Monnas, Lisa, "Dress and Textiles in the St. Louis Altarpiece: New light on Simone Martini's Working Practice," Apollo 137 (1993), 166-74.

Newton, Stella Mary, "Tomaso da Modena, Simone Martini, Hungarians and St. Martin in fourteenth-century Italy," Journal of the Warburg and Courtauld Institutes 43 (1980), 234-38.

Norman, Diana, "Politics and Piety: Locating Simone Martini's 'Saint Louis of Toulouse' altarpiece," Art History 33 (2010), 596-619.

Norman, Diana, "Sanctity, Kingship and succession: art and dynastic politics in the Lower Church at Assisi," Zeitschrift für Kunstgeschichte 73 (2010), 297-334.

Norman, Diana, "The Sicilian connection. Imperial themes in Simone Martini's St. Louis of Toulouse altarpiece," Gesta 53 (2014), 25-45.

Norman, Diana, Siena and the Angevins (1300-1350). Art Diplomacy, and Dynastic Ambition (Turnhout, 2018).

O'Meary, Carra Ferguson, Monarchy and Consent: The Coronation Book of Charles Vof France: British Library MS Cotton Tiberius B. VIII (London, 2001).

Pace, Valentino, "Friderizianische Bildnisse," in Verwandlungen des Stauferreichs, eds. Bernd Schneidmüller, Stefan Weinfurter, and Alfred Wieczorek (Darmstadt, 2010), pp. $34-52$.

Paone, Stefania, "Giotto e il 'ritratto' dei committenti," in Giotto pictor egregius, ed. Alessandro Tomei (Torino, 2017), pp. 319-353.

Paone, Stefania, "Giotto ritrattista ? Qualche considerazione," in La fantasia e la storia. Studi di storia dell'arte sul ritratto dal Medioevo al Contemporaneo, ed. Giulio Brevetti (Palermo, 2019), pp. 47-61. 
Paravicini Bagliani, Agostino, "Il busto di Bonifacio VIII. Nuove testimonianze e una rilettura," in Arnolfo di Cambio e la sua epoca, ed. Vittorio Franchetti Pardo (Rome, 2006), pp. 189-96.

Paravicini Bagliani, Agostino, "Les portraits de Boniface VIII: une tentative de synthèse," in Le portrait. La représentation de l'individu, ed. Agostino Paravicini Bagliani (Florence, 2007), pp. 117-39.

Paravicini Bagliani, Agostino, "Boniface VIII en images. Vision d'Eglise et mémoire de soi," in Le portrait individuel. Réflexions autour d'une forme de représentation XIIIeXVe siècles, ed. Dominic Olariu (Bern, 2009), pp. 83-102.

Perkinson, Stephen, "Rethinking the Origins of Portraiture," Contemporary Approaches to the Medieval Face. Gesta 46/2 (2007), 135-57.

Perkinson, Stephen, "Portraits \& their Patrons: Reconsidering Agency in Late Medieval Art," in Patronage: Power \& Agency in Medieval Art, ed. Colum Hourihane (Princeton NJ, 2013), pp. 237-54.

Perriccioli Saggese, Alessandra, "Cristophoro Orimina: an illuminator at the Angevin court of Naples," in The Anjou Bible. A royal Manuscript revealed. Naples 1340, eds. Lieve Watteeuw, and Jan van der Stock (Paris, 2010), pp. 113-25.

Perriccioli Saggese, Alessandra, "Il ritratto a Napoli nel Trecento : l'immagine di Roberto d'Angiò tra pittura e miniatura," in La fantasia e la storia. Studi di storia dell'arte sul ritratto dal Medioevo al Contemporaneo, ed. Giulio Brevetti (Palermo, 2019), pp. 37-45.

Pisani, Giuliano, I volti segreti di Giotto (Milan, 2008).

Polzer, Joseph, "Simone Martini's two frescoes in the lower right transept of the church of San Francesco in Assisi," Arte cristiana, n.s. 72 (1984), 353-68.

Praske, Tanja, Ludwig IX. der Heilige - eine Zäsur für die monumentale französische Königsdarstellung. Bildkonzepte der Zeit Philipps IV., PhD thesis (Frankfurt am Main, 2015).

Prinz, Wolfram, "Ritratto istoriato oder das Bildnis in der Bilderzählung. Ein frühes Beispiel van Giotto in der Bardikapelle," Mitteilungen des Kunsthistorischen Institutes in Florenz 30 (1986), 577-80.

Rash, Nancy, "Boniface VIII and Honorific Portraiture: Observations on the Half-Length Image in the Vatican," Gesta 26 (1987), 47-58.

Recupido, P. Giovanni, Il beato Donato sepolto in San Lorenzo Maggiore di Napoli (Naples, 1972).

Reudenbach, Bruno, "Individuum oder Bildnis? Zum Problem künstlerischer Ausdrucksformen von Individualität im Mittelalter," in Individuum und Individualität im Mittelalter, eds. Jan A. Aertsen, and Andreas Speer (Berlin, 1996), pp. 807-18.

Romano, Serena, "Introduzione: la cattedrale di Napoli, i vescovi e l'immagine. Una storia di lunga durata," in Il Duomo di Napoli, dal paleocristiano all'età angioina, eds. Serena Romano, and Nicolas Bock (Naples, 2002), pp. 7-20. 
Romano, Serena, La O di Giotto (Milan, 2008).

Romano, Serena, "Per la data della 'Crocifissione' nel transetto nord della chiesa inferiore di Assisi," Zeitschrift für Kunstgeschichte 78 (2015), 345-55.

Rubinstein, Nicolai, The Palazzo Vecchio, 1298-1532. Government, architecture, and Imagery in the Civic Palace of the Florentine Republic (Oxford, 1995).

Saenger, Ernst, "Das Lobgedicht auf König Robert von Anjou. Ein Beitrag zur Kunstund Geistesgeschichte des Trecento," Jahrbuch der Kunsthistorischen Sammlungen in Wien 84 (1988), 7-91.

Sculture trecentesche in S. Lorenzo Maggiore a Napoli, ed. Raffaele Mormone (Naples, 1973).

Seidel, Max, "Das gemeißelte Bild im Trecento. Ein neuentdecktes Meisterwerk von Tino di Camaino," Pantheon 47 (1988), 4-13.

Seidel, Max, "The sculpted image. Tino da Camaino measures up to Simone Martini," in Italian Art of the Middle Ages and the Renaissance, 2 vols, Architecture and Sculpture 2, ed. Max Seidel (Venice, 2005), pp. 627-38.

Seiler, Peter, "Giotto als Erfinder des Porträts," in Das Porträt vor der Erfindung des Porträts, eds. Martin Büchsel, and Peter Schmid (Mainz, 2003), pp. 153-72.

Sherman, Claire Richter, The portraits of Charles Vof France (1338-1380) (New York, 1969).

Smout, Caroline, Sprechen in Bildern - Sprechen über Bilder: die allegorischen Ikonotexte in den Regia Carmina des Convenevole da Prato (Köln, 2017).

Steinke, Hubert, "Giotto und die Physiognomik," Zeitschrift für Kunstgeschichte 59 (1996), 523-47.

Strehlke, Carl, "Francis of Assisi. His Culture, His Cult and His Basilica," The Treasury of Saint Francis of Assisi. Exhibition catalogue New York, Metropolitan Museum, eds. Giovanni Morello, and Laurence B. Kanter (Milan, 1999), pp. 23-51.

The Anjou Bible. A royal Manuscript revealed. Naples 1340, eds. Lieve Watteeuw, and Jan van der Stock (Paris, 2010).

Thomann, Johannes, "Pietro d'Abano on Giotto," Journal of the Warburg and Courtauld Institutes 54 (1991), 238-44.

Tomasi, Michele, "Il ritratto nel medioevo: una cornice," in Intorno al ritratto. Origini, sviluppi e trasformazioni. Studi a margine del saggio di Enrico Castelnuovo, Il significato del ritratto pittorico nella società (1973), eds. Fabrizio Crivello, and Laura Zamparo (Turin, 2019), pp. 83-92.

Tomei, Alessandro, and Paone, Stefania, "Paintings and Miniatures in Naples. Cavallini, Giotto, and the Portraits of King Robert," in The Anjou Bible. A royal Manuscript revealed. Naples 1340, eds. Lieve Watteeuw, and Jan van der Stock (Paris, 2010), pp. 53-71.

Tomei, Alessandro, "I Regia Carmina dedicati a Roberto d'Angiò nella British Library di Londra: un manoscritto tra Italia e Provenza," Arte medievale 6/4 (2016), 201-12. 
Vagnoni, Mirko, "Una nota sulla regalità sacra di Roberto d'Angiò alla luce della ricerca iconografica," Archivio storico italiano 167 (2009), 253-67.

Vagnoni, Mirko, "Royal Images and Sacred Elements in Norman-Swabian and AngevinAragonese Kingdom of Sicily," Eikon/Imago 4 (2013), 107-22.

Vitolo, Paola, "Imprese artistiche e modelli di regalità al femminile nella Napoli della prima età angioina," Archivio storico per le province napoletane 126 (2009), 1-54.

Vitolo, Paola, "Ecce rex vester. Christiformitas e spazio liturgico," in La chiesa e il convento di Santa Chiara. Committenza artistica, vita religiosa e progettualità politica nella Napoli di Roberto d'Angiò e Sancia di Maiorca, eds. Francesco Aceto, Stefano D’Ovidio, and Elisabetta Scirocco (Battipaglia, 2014), pp. 227-74.

Volpe, Carlo, "Proposte per il problema di Pietro Lorenzetti," Paragone 23 (1951), 13-26. von Moos, Peter, Unverwechselbarkeit: Persönliche Identität und Identifikation in der vormodernen Gesellschaft (Cologne, 2004).

Walter, Ingeborg, and Piccialuti, Maura, "Bartholomeo da Capua," in Dizionario biografico degli Italiani 6 (Rome, 1964), pp. 697-704.

Weiger, Katharina, "The portraits of Robert of Anjou: self-representation as political instrument?," Journal of Art Historiography 17 (2017), 1-16.

Wright, Georgia Sommers, "A Royal Tomb Program in the Reign of St. Louis," Art Bulletin 56 (1974), 224-43.

Wright, Georgia Sommers, "The Reinvention of the Portrait Likeness in the Fourteenth Century," Robert Branner and the Gothic. Gesta 39/2 (2000), 117-34. 


\section{Illustrations}

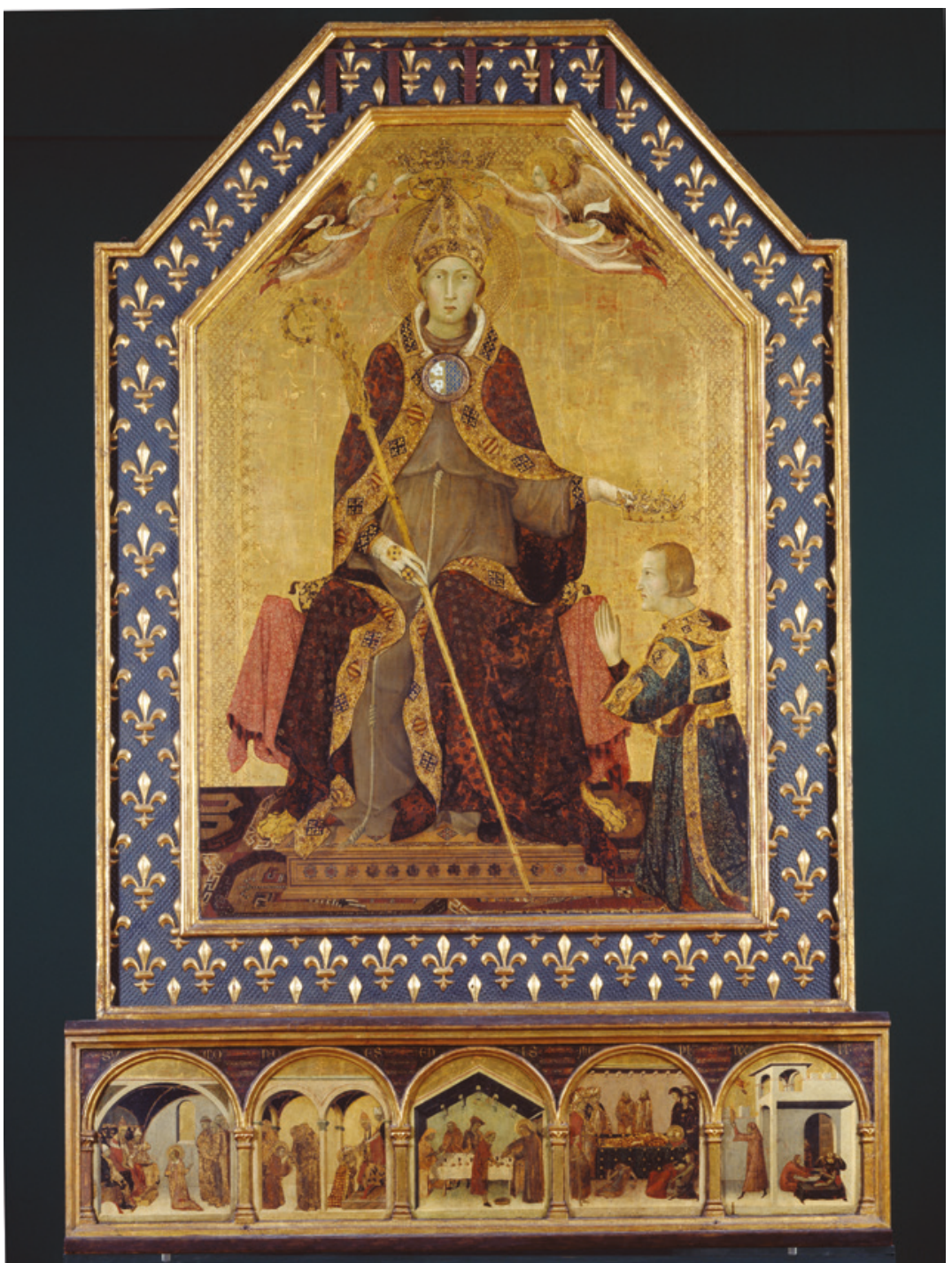

FIGURE 7.1 Simone Martini, Saint Louis of Toulouse in majesty, Naples, Capodimonte, $1317-1319$

(C) ARCHIVI ALINARI, FIRENZE 


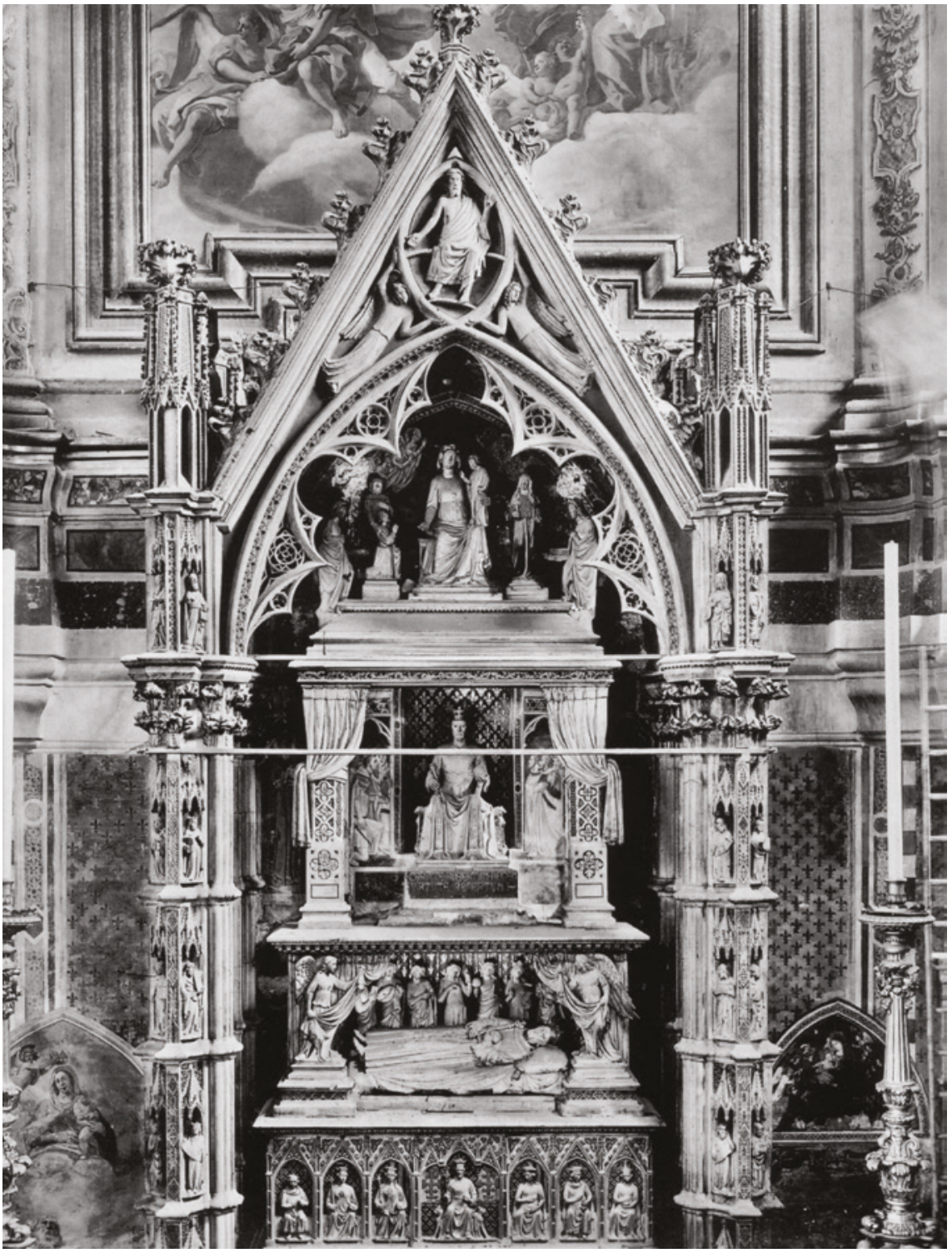

FIGURE 7.2 Giovanni and Pacio Bertini, funeral monument of Robert the Wise (†1343), Naples, S. Chiara, $1343^{-c .1346}$

(C) LUCIANO PEDICINI, NAPLES 


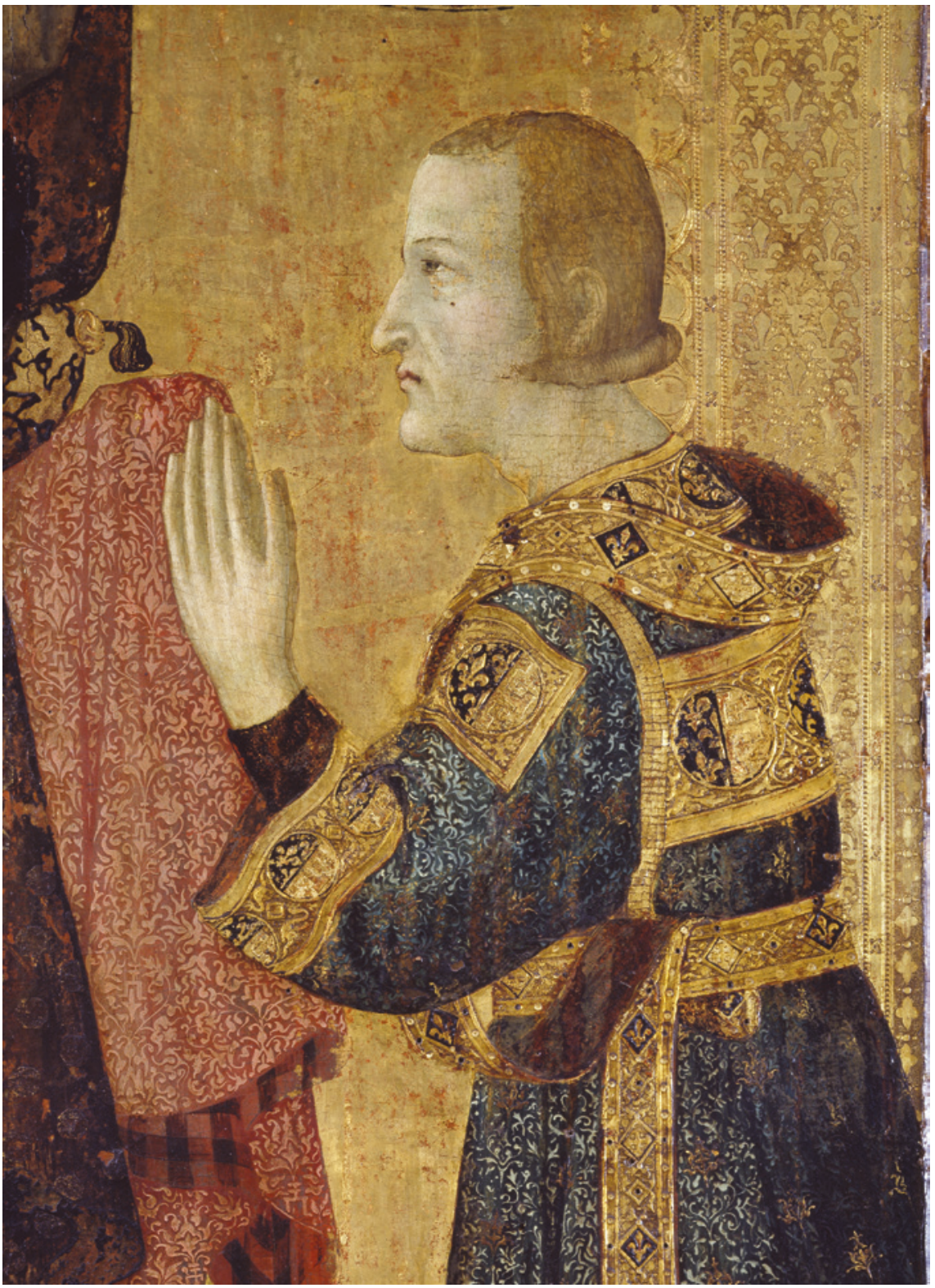

FIGURE 7.3 Simone Martini, Saint Louis of Toulouse in majesty, Detail, Robert of Anjou, Naples, Capodimonte,1317-1319

(C) LUCIANO PEDICINI, NAPLES 


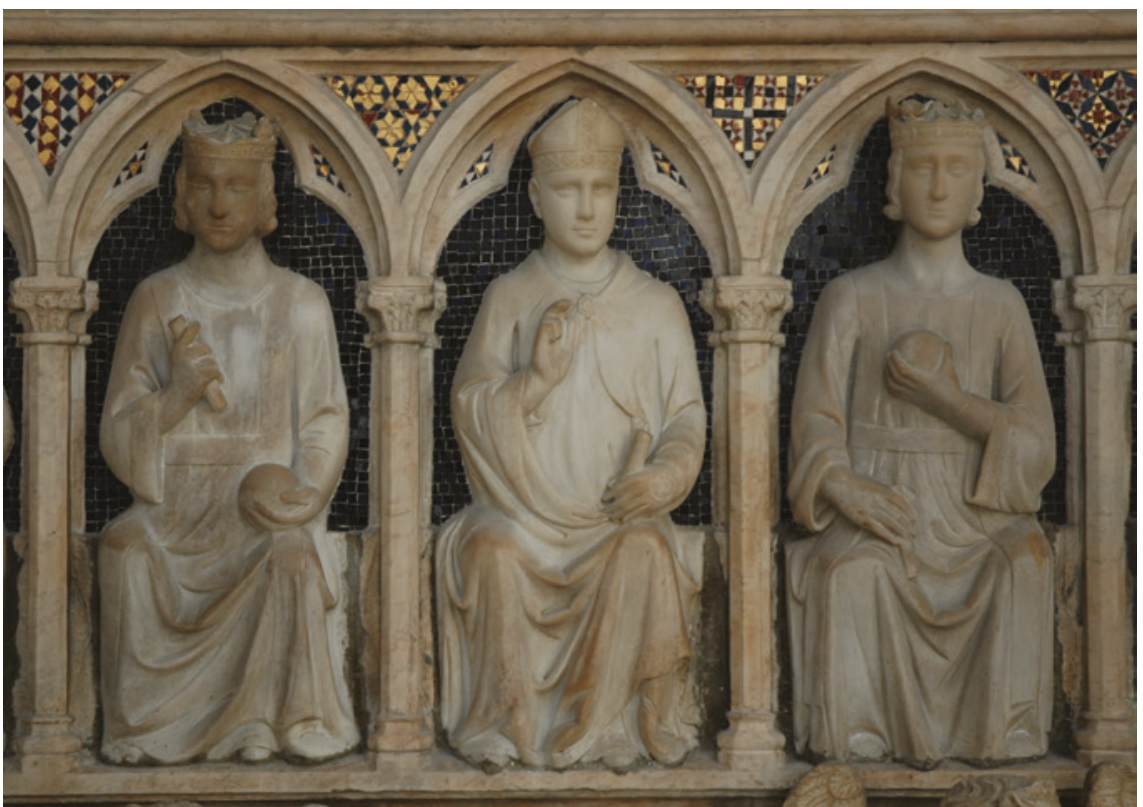

FIGURE 7.4 Tino di Camaino, Louis of Toulouse, Charles Martel and Robert of Anjou, funeral monument of Mary of Hungary ( $† 1323$ ), Naples, S. Maria Donnaregina, 1325-1326 (C) AUTHOR 


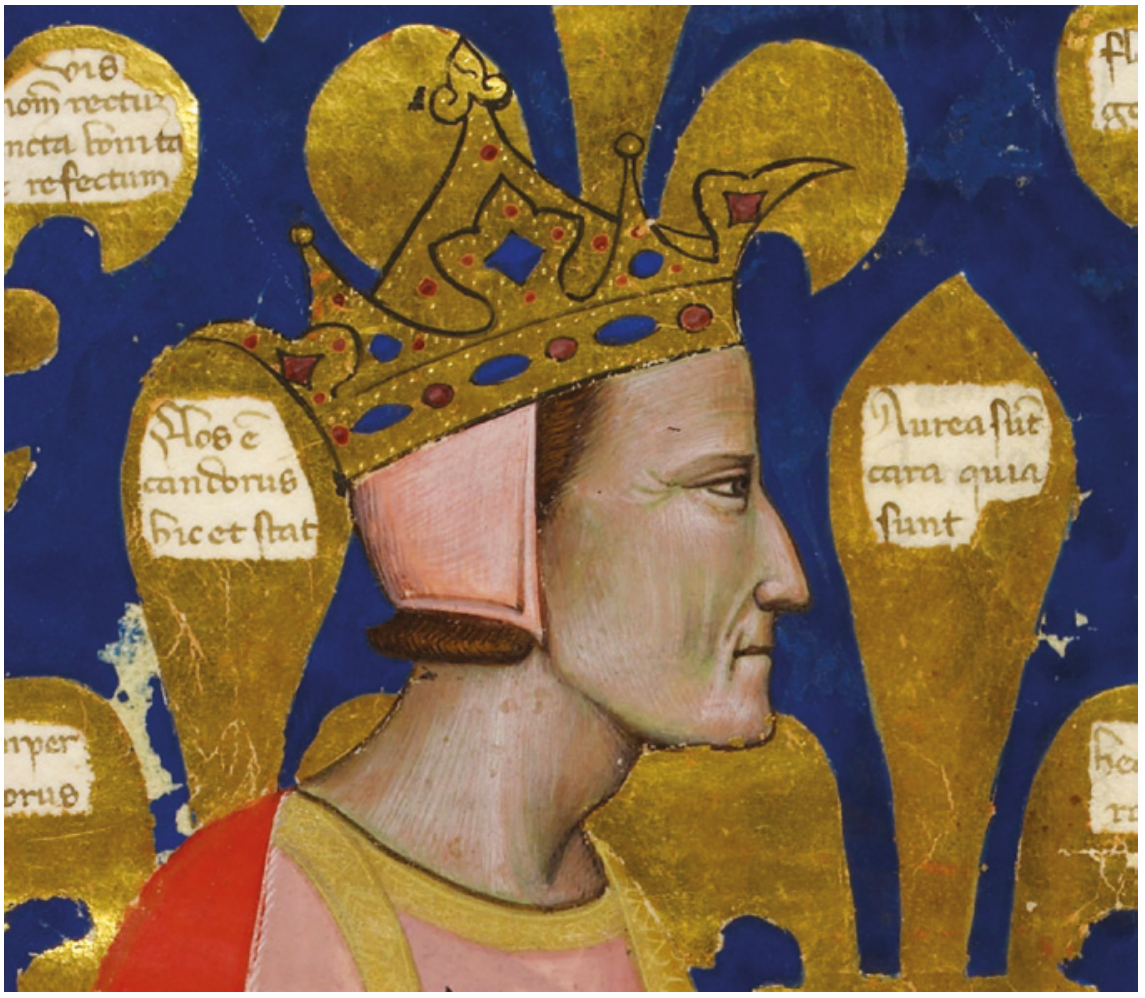

FIgure 7.5 Convenevole da Prato / Pacino da Buonaguida, Robert of Anjou, Regia Carmina, London, BL, MS Royal 6 E IX, fol. 11v, 1335-1336

(C) BRITISH LIBRARY BOARD 


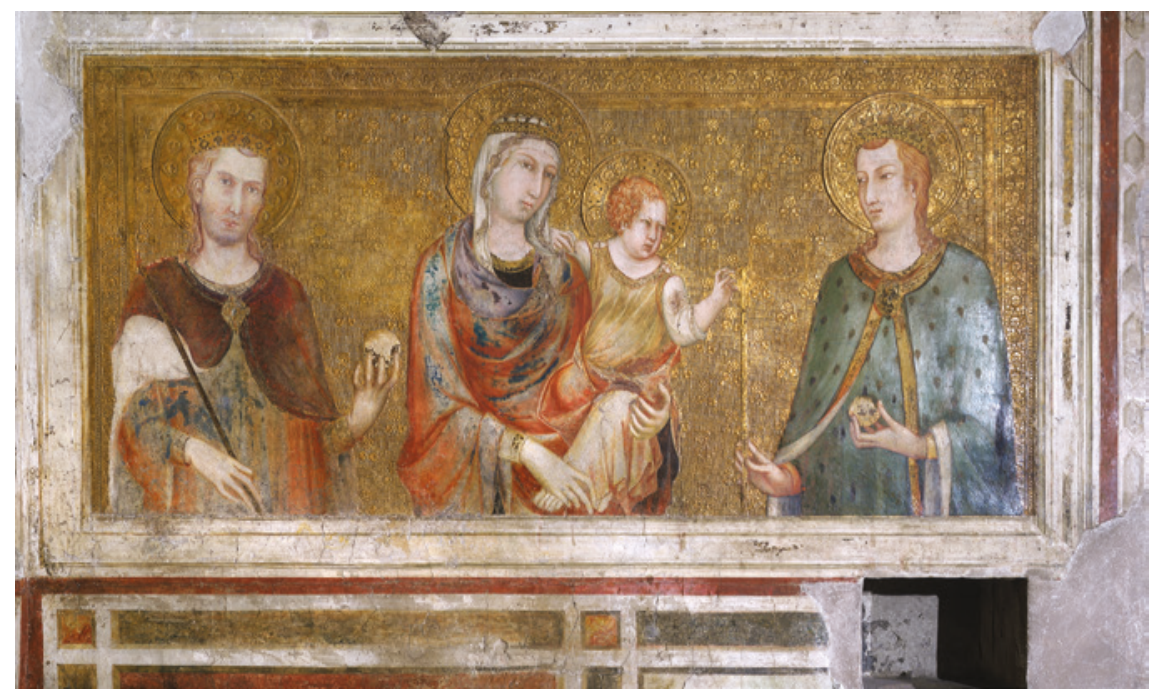

FIG URE 7.6 Simone Martini, Assisi, Virgin and Child, flanked by Saint Ladislaus and Saint Elizabeth of Hungary, lower church, north transept, east wall (St. Elizabethchapel), c. 1317

(C) STEPHAN DILLER

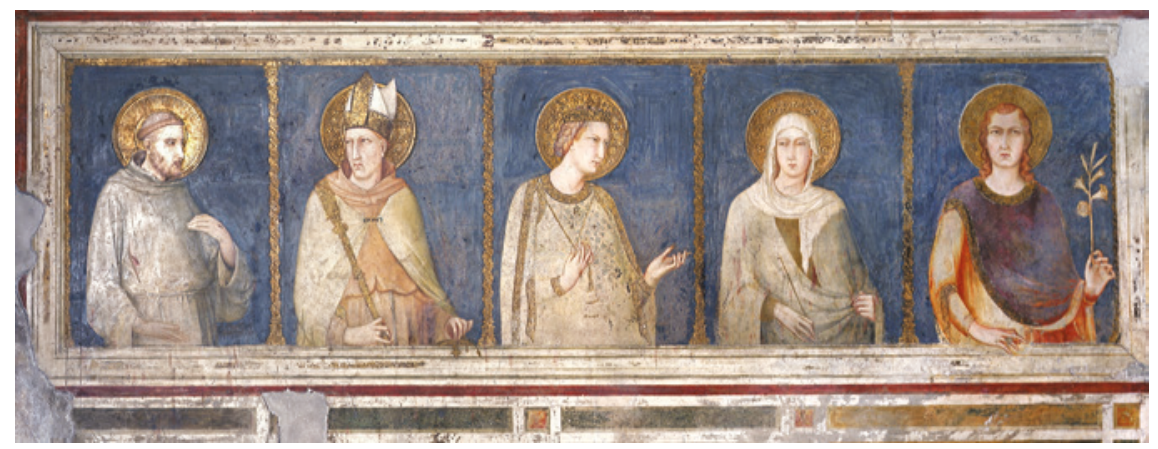

FIGURE 7.7 Simone Martini, Saints Francis, Louis of Toulouse, Elizabeth, Agnes of Bohemia, and Henry of Hungary, Assisi, lower church, north transept, north wall (St. Elizabeth-chapel), c. 1317

(C) STEPHAN DILLER 


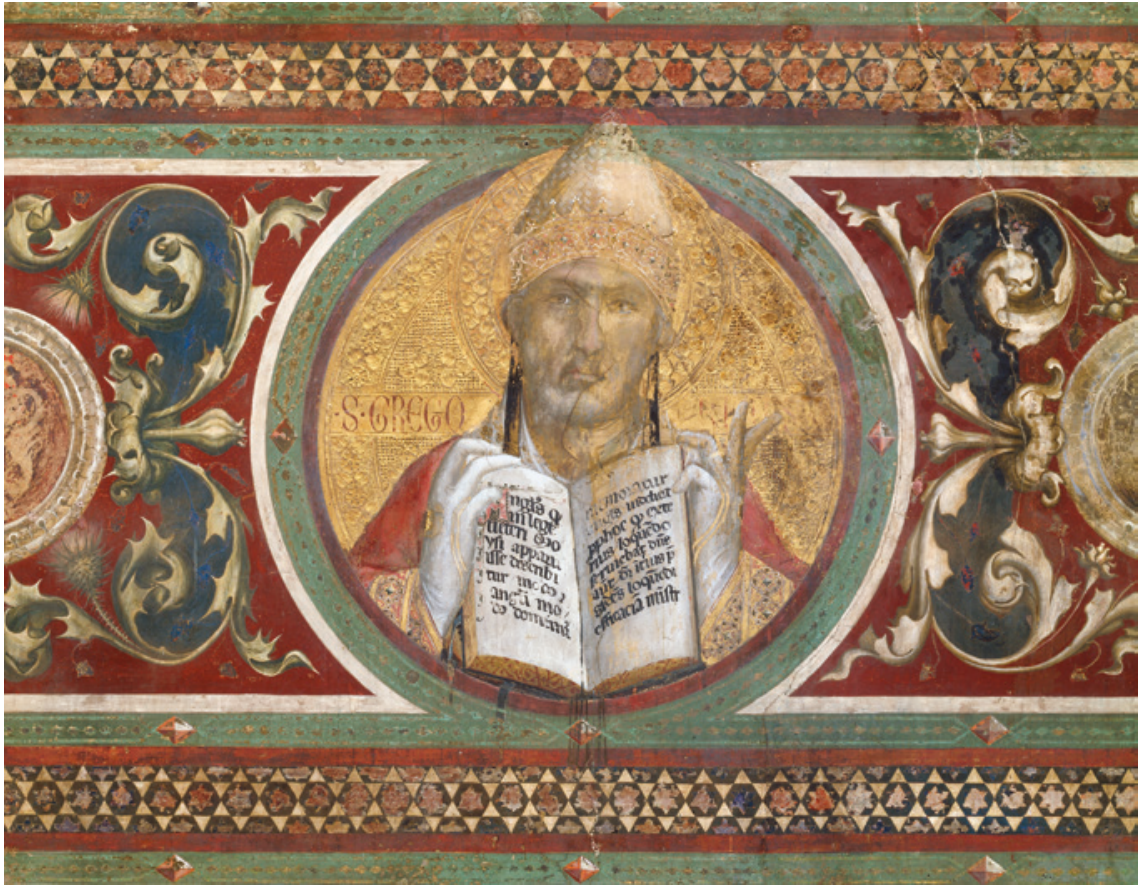

FIGU Re 7.8 Simone Martini, Maestà, Detail: Saint Gregory, Siena, Palazzo Pubblico, 1321 (C) 2020 PHOTO SCALA, FLORENCE

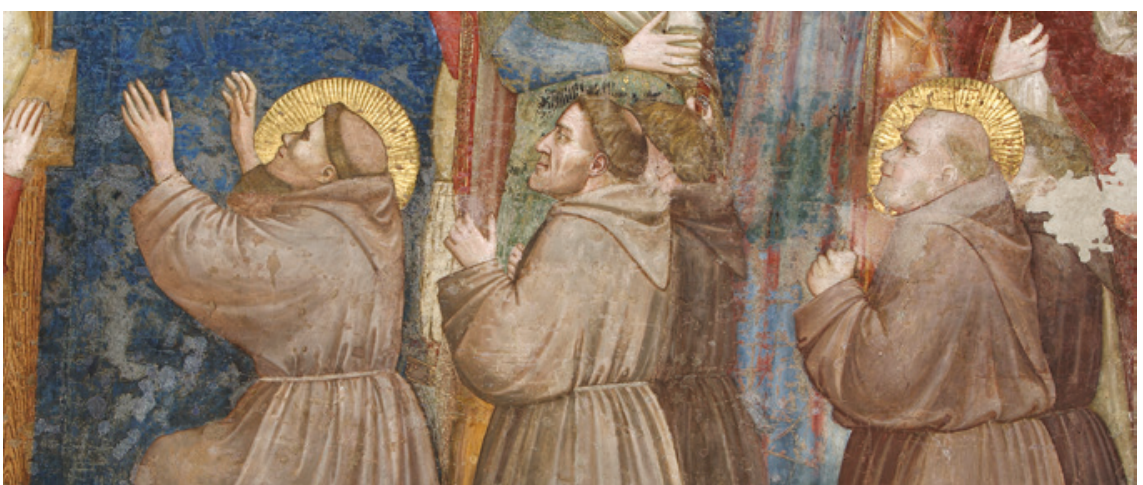

FI GURE 7.9 Giotto, Crucifixion, Detail: Saint Francis, Fra Gonsalvo di Valboa (?), Saint Anthony, Assisi, lower church, south transept, east wall, c. 1313 (C) STEPHAN DILLER 


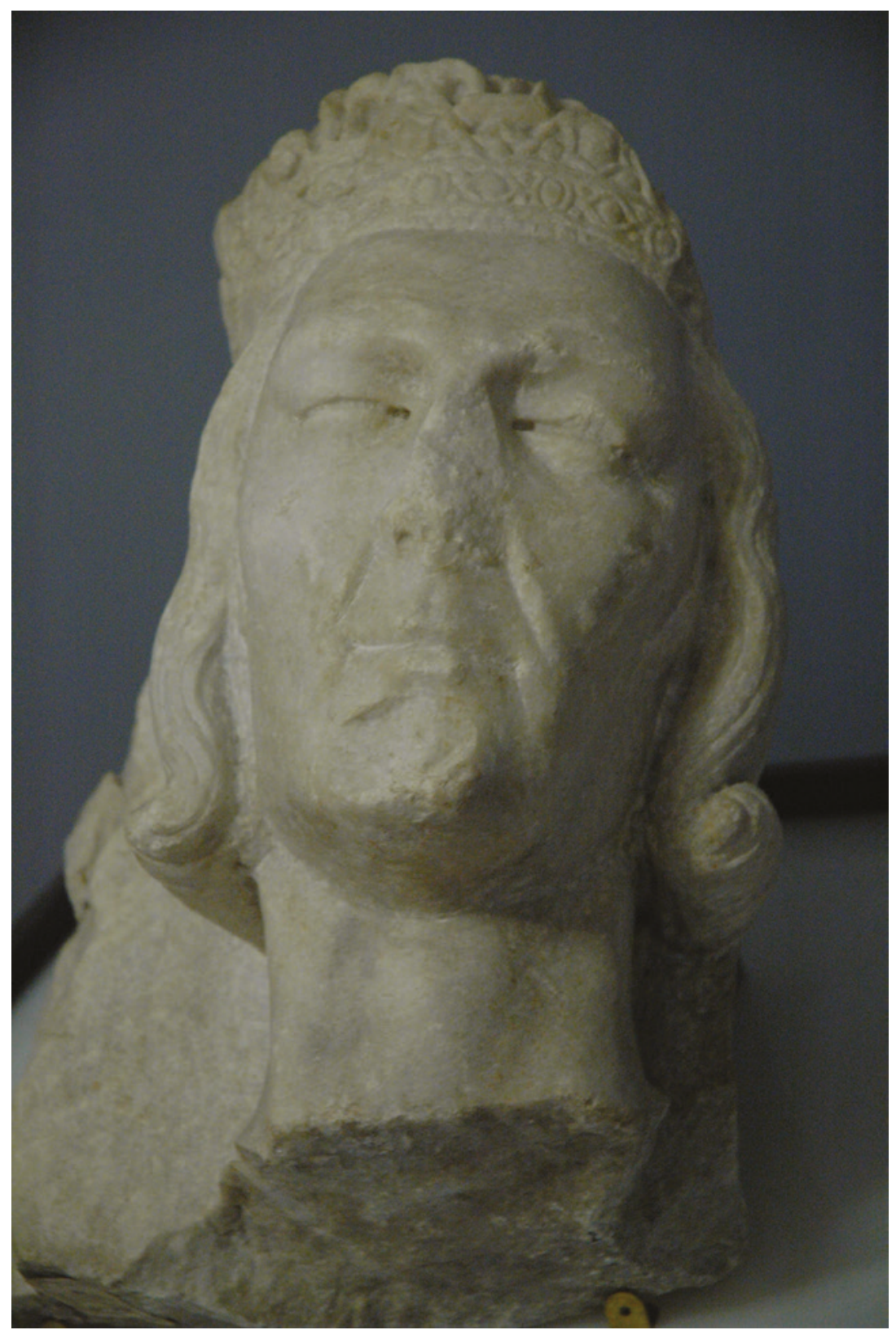

FIGURE 7.10 Workshop of Tino da Camaino (?), Head of Charles I, Naples, Museo di Capodimonte, 1333

(C) AUTHOR 


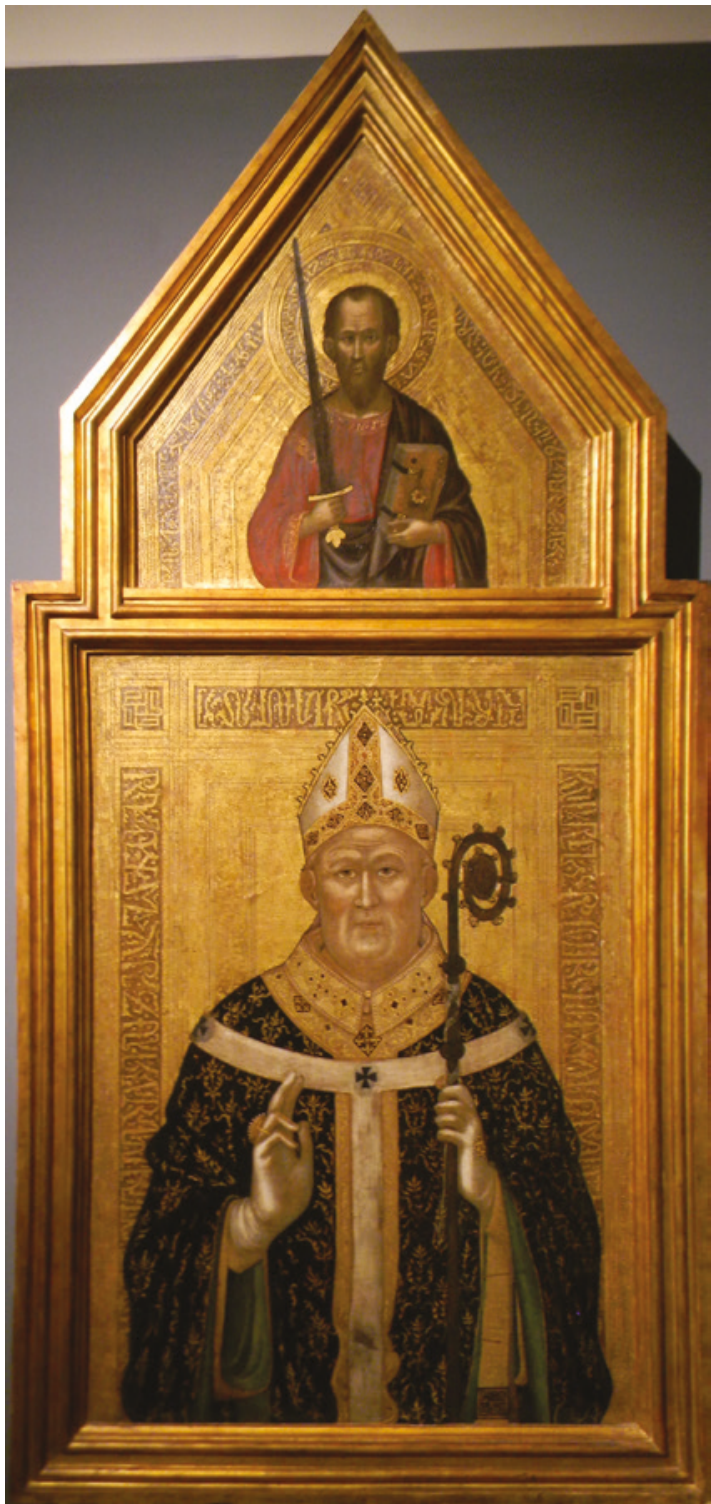

FIgURE 7.11 Lello d'Orvieto, Portrait of archbishop Umberto d'Ormont, Naples, Museo Diocesano, 1320

(C) AUTHOR 


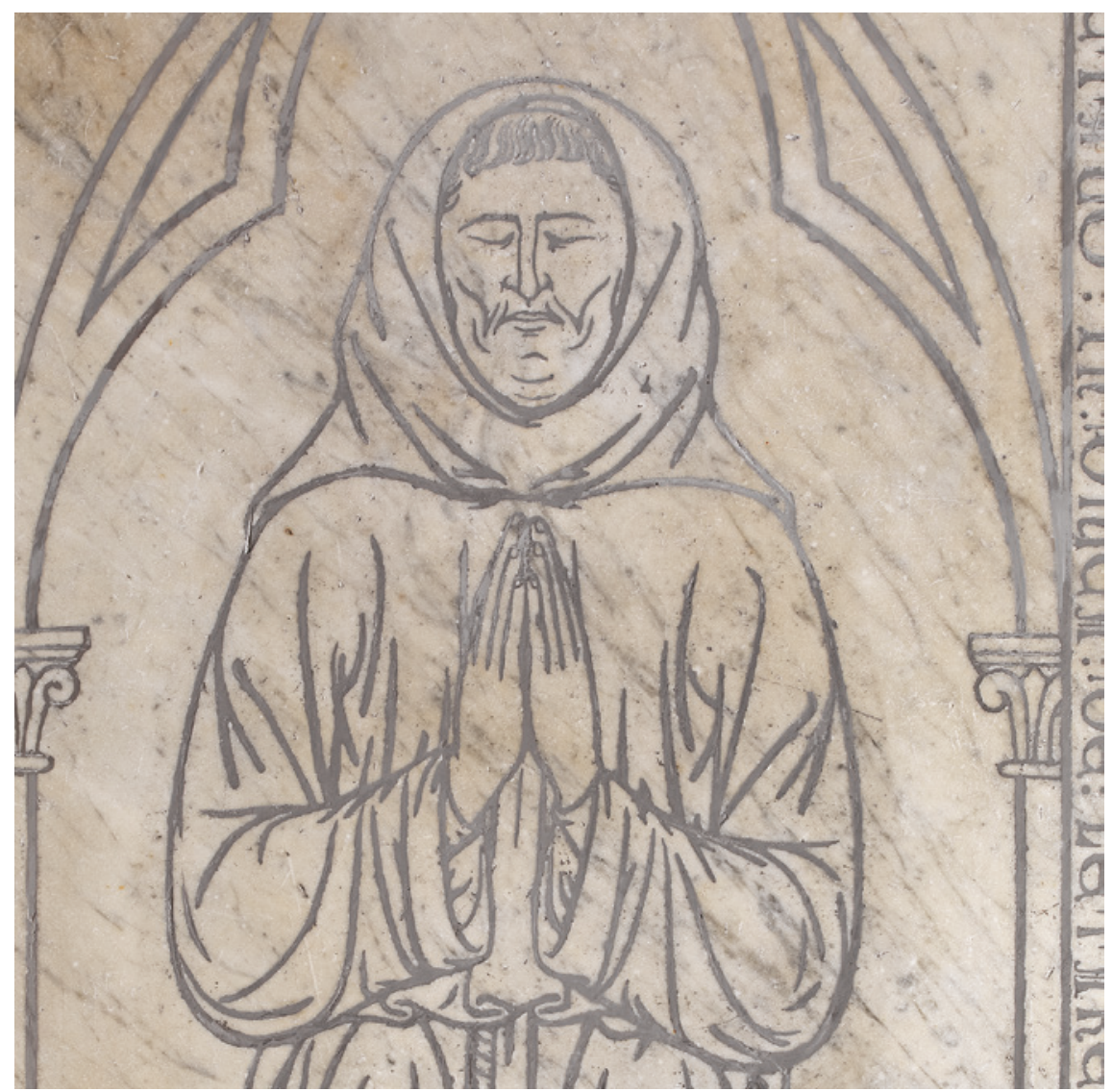

FIGURE 7.12 Tomb slab of Fra Donato, Naples, San Lorenzo Maggiore, 1308 (c) LUCIANO PEDICINI, NAPLES 